\title{
Assessment of the global and regional geographical, technical and economic potential of onshore wind energy
}

\author{
Monique Hoogwijk ${ }^{\mathrm{a}}$, Bert de Vries ${ }^{\mathrm{b}}$, Wim Turkenburg ${ }^{\mathrm{a}, *}$ \\ ${ }^{a}$ Department of Science, Technology and Society, Copernicus Institute for Sustainable Development and \\ Innovation, Utrecht University, Heidelberglaan 2, 3584 CH Utrecht, The Netherlands \\ ${ }^{\mathrm{b}}$ National Institute of Public Health and the Environment (RIVM), Bilthoven, The Netherlands
}

Available online 21 July 2004

\begin{abstract}
The regional and global geographical, technical and economic potential of onshore wind energy is assessed using a grid cell approach. For the economic potential, the regional cost-supply curves of wind electricity are presented. The global technical potential of wind electricity is estimated to be 96 PWh year ${ }^{-1}$ : about 6-7 times the present (2001) world electricity consumption at cut-off costs of about $1 \mathrm{US} \$ \mathrm{kWh}^{-1}$. To realise this potential, an area of $1.1 \mathrm{Gha}$ is required when the wind turbines are installed at an average power density of $4 \mathrm{MW} \mathrm{km}^{-2}$. This is similar to the total global grassland area or to an area with the size of about China. The regionally highest technical potential of onshore wind energy is found for USA: $21 \mathrm{PWh}_{\text {year }}{ }^{-1}$. Lowest figures are found for South East Asia, Southern and Western Africa and Japan. With present day technology, roughly an amount equal to the present (2001) world electricity consumption can be generated at a cost of $0.07 \mathrm{US} \$ \mathrm{kWh}^{-1}$ and below, mainly in Canada, USA, South America, OECD Europe and the former USSR.

(C) 2004 Elsevier B.V. All rights reserved.
\end{abstract}

JEL classification: Q41; Q42

Keywords: Wind energy; Global resource; Cost-supply curve

\section{Introduction}

The power in the wind has been utilised for many centuries. The first windmills were used mainly for grinding grain and pumping water in Persia about AD 500-900. These were vertical axis systems (Dodge, 2001). There is proof that in China and Tibet, horizontal axis

* Corresponding author. Tel.: +31-30-2537600; fax: +31-30-2537601.

E-mail address: W.C.Turkenburg@chem.uu.nl (W. Turkenburg). 
windmills were used about AD 1000. By AD 1800, about 20,000 modern windmills were in operation in France alone and in the Netherlands about $90 \%$ of the power used in industry was based on wind energy (Ackermann and Soeder, 2002). In 1891, the pioneering Dane Poul LaCour built the first wind energy turbine that generated electricity. The large-scale development of wind energy began after the oil crises in the 1970s, with wind farms being installed in California under an attractive tax scheme. At the beginning of the 1990s, the USA was leading in installed wind energy capacity. Germany took over around the mid1990s due to effective government intervention. At the start of 2003, the world-installed capacity of wind energy was $31.162 \mathrm{GW}^{1}$ against $2 \mathrm{GW}$ in 1991 . The main countries involved are Germany, USA, Spain, Denmark and India. In the last 5 years, the capacity increased annually by about $30 \%$. The largest annual increase at country level (48\%), in the period 1991-2001, was in Germany (European Commission, 1999; Morthorst, 1998).

The rapid growth in wind capacity is reflected in the development of wind turbine technology. A significant trend is the upscaling of the size of the turbines, increasing their output and reducing the generation costs and the visual impact on the landscape (Beurksens, 1999). The average size of installed commercial turbines has increased from about $30 \mathrm{~kW}$ in the mid-1970s (rotor diameter about $10 \mathrm{~m}$; Beurksens, 1999) to $1 \mathrm{MW}$ at present (rotor diameter about $80 \mathrm{~m}$; Ackermann and Soeder, 2002). The largest commercial wind turbines now available are $2 \mathrm{MW}$. Wind turbines of $3 \mathrm{MW}$ or more are under development. Other developments over the last few decades are better control and power regulation systems and focus on direct drive turbines. The latter involve higher investment costs (Bundesverband WindEnergie, 1995-2000, 2001), but the direct drive turbine cost may be lower because no gearbox is needed. Furthermore, the energy conversion efficiency is improved (BTM, 2001; European Commission, 1999).

As illustrated, there is recently a large policy interest in wind energy based on various arguments. First, wind energy reduces dependency on and payments for imported fuels. Second, it diversifies energy carriers for the production of electricity. Furthermore, it can increase the flexibility of the electricity system as demand changes and it saves fossil fuels for other applications and future generations. Finally, wind electricity reduces pollution and emissions, such as $\mathrm{NO}_{x}$ and $\mathrm{CO}_{2}$, that are produced by conventional energy systems (Turkenburg, 2000). As wind energy becomes more and more competitive, many authors expect that a strong growth of installed wind turbines continues for a number of decades (BTM, 2001; IPCC, 2000; Johansson et al., 1993; Lazarus, 1993; Shell, 1995; World Energy Council, 1994; EWEA and Greenpeace, 2002; Turkenburg, 2000).

The global potential of wind energy has been assessed in previous studies. All have concluded that its (onshore) technical potential is sufficient to supply several times the total world electricity demand in 1990 (e.g., (Grubb and Meyer, 1993; World Energy Council, 1994; Fellows, 2000)). However, a new evaluation of the potential of onshore wind electricity is useful for three reasons:

- The studies (except Fellows, 2000) have resulted in aggregate estimations of the theoretical and technical potential and have dealt in only a limited way with the spatial

1 The figures of the global installed wind energy capacity is kept up to date by the "Windicator", see http:// www.wpm.co.nz/windicat.htm. 
distribution of wind turbine applications. The assessment can be improved by systematically using spatial data on average wind speed, land-use and land-cover data.

- Only two studies (World Energy Council, 1994; Fellows, 2000) have included economic factors in the assessment. However, the cost data of the World Energy Council (WEC) are now out of date and the Fellows (2000) only focuses in detail on four regions. The assessment can be improved using recent knowledge on wind electricity production costs around the world.

- The methodological approach in previous studies has been applied on wind energy only. We have also applied the approach to assess the potential of biomass energy and photovoltaic electricity using the same background data for the spatial distribution of land-use and population as in Hoogwijk et al. (submitted for publication). This enables to compare the potentials and simulate the future role of different renewable energy sources in the electricity market using an energy model such as TIMER 1.0 (de Vries et al., 2002).

Therefore, this study analyses the potential of onshore wind electricity. First, we assess the worldwide theoretical, geographical and technical potential of onshore wind energy for electricity generation based on present day technology. Second, we estimate the production cost of wind electricity and construct wind energy cost curves as a function of the technical potential. The study is conducted at a global level using a $0.5^{\circ} \times 0.5^{\circ}$ (longitude, latitude $)^{2}$ land-use grid and a division of the world into 17 regions. We evaluate the major uncertainties and assess the sensitivity for key assumptions.

We first describe the approach and definitions used (Section 2) by defining four categories of wind energy potential and by describing how the cost-supply curves are constructed. Next, we present the methodology used and the results found for each potential category (Sections 3-6). Section 7 contains a discussion of the results and a sensitivity analysis. We compare our study with other studies and evaluate the approach and input parameters. The final section presents conclusions that can be drawn from this study.

\section{Approach and definitions}

Consistent with the approach developed at Utrecht University (van Wijk and Coelingh, 1993) and published by the WEC (World Energy Council, 1994), we define four categories of wind energy potential, namely, the theoretical, the geographical, the technical and the economic potential. Each category narrows down the previous one because it includes certain limitations and obstacles:

- Theoretical potential: The total global energy content of the wind ( $\left.\mathrm{kWh}_{\text {year }}{ }^{-1}\right)$;

- Geographical potential: The total global amount of land area available for wind turbine installation taking geographical constraints into account $\left(\mathrm{km}^{2}\right)$;

\footnotetext{
2 The order of magnitude $0.5 \times 0.5^{\circ}$ means that in total, there are about 66,000 onshore cells. At the equator, the grid cells measure $3025 \mathrm{~km}^{2}$. The Netherlands is divided into about 15 cells.
} 
- Technical potential: The wind power generated at the geographical potential including energy losses due to the power density of the wind turbines and the process of generating electricity using wind turbines $\left(\mathrm{kWh}\right.$ year $\left.^{-1}\right)$;

- Economic potential: The technical potential that can be realised economically given the cost of alternative energy sources $\left(\mathrm{kWh}_{\mathrm{Wear}}{ }^{-1}\right)$.

We realise that the separate categories are not strictly defined and may be interpreted in different ways. However, the sequence included in the categories allows us to study the constraints that reduce the potential of wind energy. This gains insight in the factors important for the potential of wind energy.

For completeness, we also mention an additional category defined by van Wijk and Coelingh (1993), the implementation potential. Although the factors that are introduced in this type of potential are partly taken into account in this study in the geographical potential, the implementation potential is not studied in here:

- Implementation potential: The amount of economic potential that can be implemented within a certain timeframe, taking (institutional) constraints and incentives into account $\left(\mathrm{kWh}\right.$ year $\left.^{-1}\right)$.

To analyse the implementation potential, one needs a quantification of the electricity system and of important social values and institutional interventions such as subsidies,

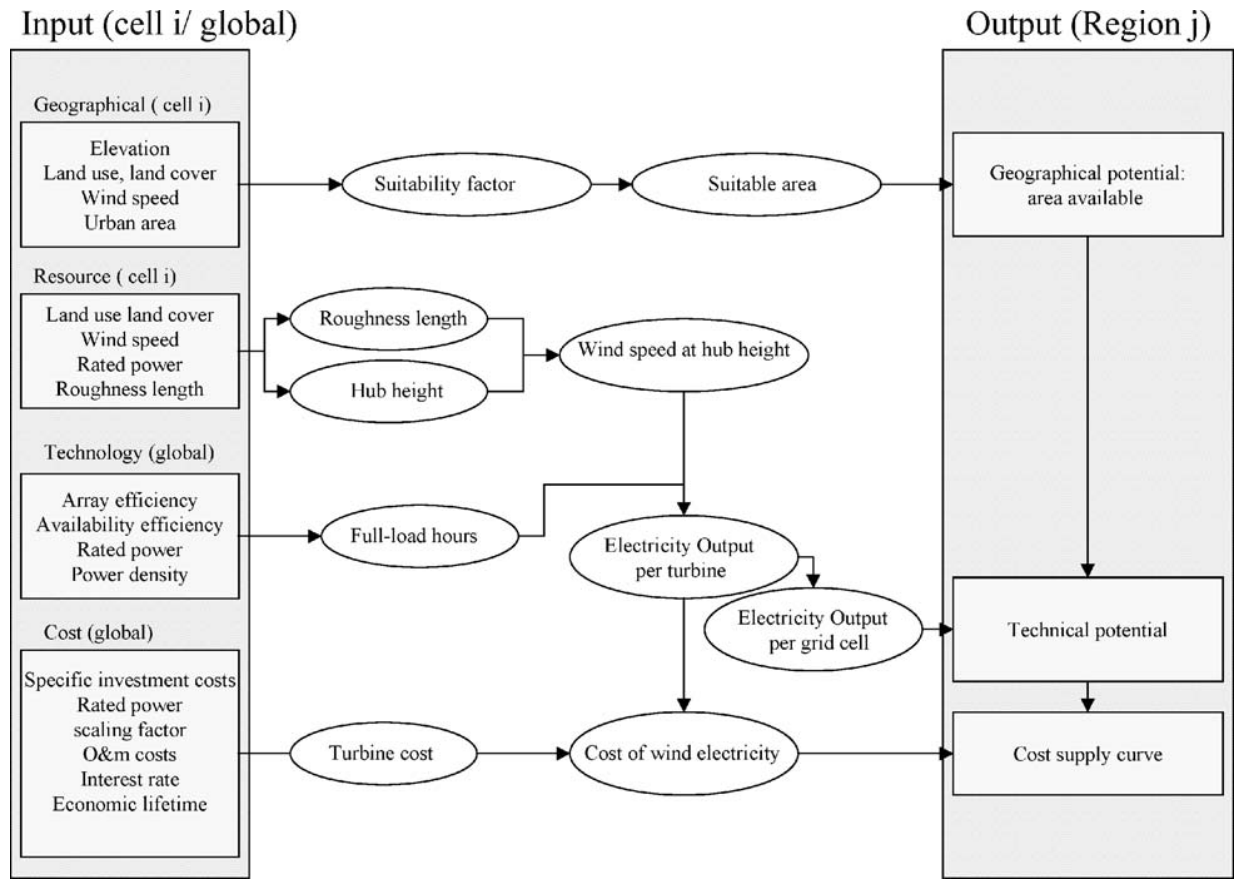

Fig. 1. Outline of the calculation of the wind energy potentials. 
tolerated investment risks, local preferences on landscape, etc. These cannot be evaluated unless one defines a specific quantitative scenario based on population and economic dynamics. Possible barriers to implementation are visual and financial constraints or competition with other power generation options. However, it should be noticed that various social factors may already be encountered when estimating the geographical and technical potential. The assessment of the potentials is done at geographical grid cell level $\left(0.5^{\circ} \times 0.5^{\circ}\right)$, the results being aggregated to 17 regions: Canada, USA, Central America, South America, Northern Africa, Western Africa, Eastern Africa, Southern Africa, OECD Europe, Eastern Europe, former USSR, Middle East, South Asia, East Asia, South East Asia, Oceania and Japan. These are consistent with the regions defined in the IMAGE 2.2 model (Integrated Model to Assess the Global Environment, IMAGEteam, 2001). For an overview of the approach, the reader is referred to Fig. 1.

\section{Theoretical potential}

Wind originates from temperature differences on earth which cause pressure differences in the earth's atmosphere. The rotation of the earth contributes to the speed and direction of the wind. The wind contains an amount of kinetic energy that can be expressed in terms of the mass of the air and the speed of this mass. ${ }^{3}$ At grid cell level, it is conceptually difficult to calculate the power in the wind. The theoretical potential is rather derived from the theoretical solar energy reaching the atmosphere. King Hubbert (1971) estimated that the total wind power on earth is roughly equivalent to $2 \%$ of the solar energy reaching the atmosphere, which is about $3.5 \times 10^{15} \mathrm{~W}$. Expressed in energy terms, this equals $110 \mathrm{ZJ}$; about 290 times the present world energy consumption of about $400 \mathrm{EJ}$ (Goldemberg, 2000).

\section{The geographical potential}

The first reduction in the theoretical potential in this study is the restriction to onshore areas only. At present, the wind energy industry is showing much interest in offshore wind energy applications. The future of wind energy might be significantly offshore in countries with a sizeable coastal region and land scarcity, such as the UK and the Netherlands. The technical potential of offshore wind electricity production is considered to be large and generation costs may decrease to cost-effective levels (Matthies et al., 1995; de Noord, 1999). However, offshore wind energy is excluded in this study because insufficient wind speed data are available to justify a proper analysis of the global offshore wind energy potential. Studies on the wind energy offshore potential estimate its value at $37 \mathrm{PWh}$ year $^{-1}$ at $50 \mathrm{~m}$ depth, requiring 5.5 million $\mathrm{km}^{2}$, with the largest potential found in Europe (8.5 PWh year ${ }^{-1}$ ) (Leutz et al., 2001).

The onshore area available for wind power is further restricted to areas that are suitable for wind turbine installation. At the level of detail, we are working on in this study, it is

\footnotetext{
3 The kinetic potential from wind energy is expressed as: $P=(1 / 2) \rho v^{3}$, where $P$ is the power $(\mathrm{W})$ per $\mathrm{m}^{2}$ swept area, $\rho$ is the air density in $\left(\mathrm{kg} \mathrm{m}^{-3}\right)$, and $v$ is the wind speed $\left(\mathrm{m} \mathrm{s}^{-1}\right)$.
} 


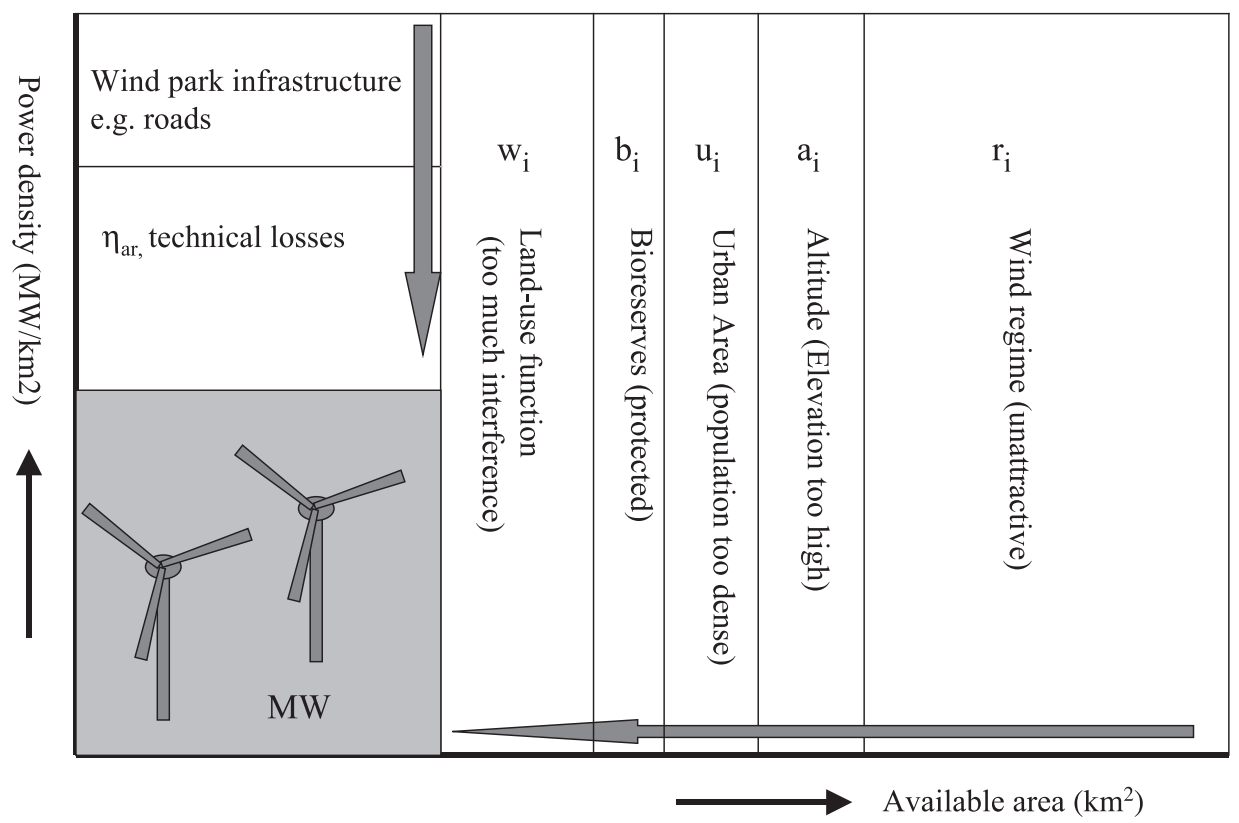

Fig. 2. The constraints reducing the area available for wind turbine installation: altitude, urban area, bioreserves and other land-use functions along the vertical axis are the constraints reducing the power density (see Section 5). The size of the boxes is illustrative.

impossible to quantify all factors involved. We consider only constraints due to the wind regime, the land-use function of the area (including bioreserves), altitude (i.e., elevation) and the urban area (percentage of settlements within a geographical grid cell). These constraints are visualised in Fig. 2. The area left after these constraints have been taken into account and is expressed as a fraction of the total area in each grid cell, the suitability factor $f_{i}$. This fraction ranges from 0 to 1 . Hence, the geographical potential in each cell $i$ $\left(\mathrm{Gp}_{i}\right)$ can be formulated as follows: ${ }^{4}$

$$
\mathrm{Gp}_{i}=A_{i} f_{i}
$$

where $\mathrm{Gp}_{i}$ is the geographical potential in grid cell $i\left(\mathrm{~km}^{2}\right), A_{i}$ is the total onshore area $\left(\mathrm{km}^{2}\right)$ in cell $i$, and $f_{i}$ is the suitability factor for sociogeographical constraints in cell $i(-)$. The $f_{i}$ is calculated from the following expression using data from the IMAGE database (IMAGEteam, 2001):

$$
f_{i}=\frac{\left(A_{i}-u_{i}\right) a_{i} w_{i} b_{i} r_{i}}{A_{i}}
$$

where $u_{i}$ is the urban area in cell $i, a_{i}$ is the binary weighting factor for altitude, $b_{i}$ is the suitability factor for bioreserves $(0$ if there are protected areas or areas with high natural

\footnotetext{
${ }^{4}$ As the theoretical potential could not be estimated in every grid cell, we express the geographical potential as the suitability factor $f_{i}$ multiplied with the area. It would have been more logical to express the geographical potential in energy terms.
} 
values and 1 for all other areas), $w_{i}$ is the suitability factor for land-use and land-cover function of cell $i$, and $r_{i}$ is the suitability factor for wind regime restrictions.

\subsection{Constraint 1: wind regime $\left(r_{i}\right)$}

The wind turbines built at present have power curves ${ }^{5}$ that can be parameterised for any wind regime. When the distribution in the wind (see Section 5) and the average wind speed are taken into account, it is technically possible to develop a wind turbine for situations with marginal wind resources. However, in reality, at these marginal sites no wind turbines will be installed since the output of a turbine in such a situation would be low, and so the cost high. Therefore, in this study we restrict the area to wind regimes with an average wind speed higher than $4 \mathrm{~m} \mathrm{~s}^{-1}$ at a height of $10 \mathrm{~m}$ at the specified resolution of $0.5^{\circ} \times 0.5^{\circ}$ based on the available Climate Research Unit (CRU) database (the database is described in Section 5). Although this wind speed value is based on arguments concerning the output of a turbine and not on geographical constraints, it is included in the geographical potential since it restricts the available area.

The criterion might be considered too loose, since other studies have assumed stricter criteria, e.g., a wind regime above 6.0 or $5.1 \mathrm{~m} \mathrm{~s}^{-1}$ at $10 \mathrm{~m}$ (Grubb and Meyer, 1993; World Energy Council, 1994), based on the assumption that wind turbines at locations with an average speed below $5.1 \mathrm{~m} \mathrm{~s}^{-1}$ at $10 \mathrm{~m}$ of height cannot generate wind electricity at economically viable levels. There are two justifications for our choice. First, we introduce a wind electricity $(\mathrm{kWh})$ - cost curve as a function of the supply (technical potential). Hence, sites with a low average wind speed end up in the upper, less attractive, part of the curve. Second, the database used in this study supplies one figure for the average wind speed at the specified resolution of $0.5^{\circ} \times 0.5^{\circ}$. The value of these figures is relatively low (see Sections 5 and 8). For instance, about $80 \%$ of the global area has an annual average wind speed lower than $4 \mathrm{~m} \mathrm{~s}^{-1}$ at $10 \mathrm{~m}$ in the CRU database (e.g., sub-Saharan Africa and the total Indian continent). If we confine the estimate to an area with an average wind speed lower than $5.1 \mathrm{~m}$ $\mathrm{s}^{-1}$, large areas that are known as areas where wind turbines are installed at present would have been cut off ( $92 \%$ as a global yearly average!).

\subsection{Constraint 2: altitude $\left(a_{i}\right)$}

We restrict the suitable area to grid cells with an average altitude below $2000 \mathrm{~m}$. Data on altitude are taken from the IMAGE 2.2 model, which assigns one value per grid cell (IMAGEteam, 2001). It is assumed that if a cell has an average altitude above this value, access would be too difficult and hardly any turbine could be installed. Furthermore, the air density - and thus the power in the wind - falls with height. The air density at $2000 \mathrm{~m}$ is reduced to a value of $0.945 \mathrm{~kg} \mathrm{~m}^{-3}$ compared to $1.29 \mathrm{~kg} \mathrm{~m}^{-3}$ at sea level at $20{ }^{\circ} \mathrm{C}$ (Lysen, 1982). This means $25 \%$ less power (see footnote 3 ). On the other hand, however, the wind

\footnotetext{
5 The power curve of a wind turbine indicates the electric output of a turbine $(\mathrm{kW})$ at various wind speeds $(\mathrm{m}$ $\left.\mathrm{s}^{-1}\right)$. It is determined by the cut-in speed ( $v_{\mathrm{i}}$; minimum wind speed for power generation), the rated wind speed $\left(v_{\mathrm{r}}\right.$; wind speed with output at rated power) and cut-out wind speed $\left(v_{\mathrm{o}}\right.$; maximum wind speed until the generator is turned off; see also Section 5).
} 
speed mostly increases with increasing altitudes. The value of $2000 \mathrm{~m}$ is rather arbitrary. It is known that wind turbines have been installed at altitudes of $1835 \mathrm{~m}$ (Oberzeiring, Austria; EWEA, 2001). Some turbines are found at higher altitudes in Latin America; however, they are not installed on a large scale.

\subsection{Constraint 3: urban area $\left(u_{i}\right)$}

We exclude urban area in our assessment because highly urbanised or otherwise densely populated regions are severely constrained as is evident in potential assessment and planning studies at national level (British Wind Energy Association, 2000; Elliot and Schwartz, 1993; EIA, 1999; Cabooter et al., 1997). Data on the urban area are obtained from the IMAGE 2.2 model. They are based on the DIScover database that supplies detailed data at $1 \times 1 \mathrm{~km}$ cells, with urban area defined as land covered by buildings and other man-made structures (Loveland and Belward, 1997; Belward and Loveland, 1995). The data have been converted to $0.5^{\circ} \times 0.5^{\circ}$ grid cells in order to construct a database that gives the fraction of urban area in each cell. This fraction is calculated by dividing the number of original $1 \times 1 \mathrm{~km}$ cells classified as 'urban and built-up' by the total number of $1 \times 1 \mathrm{~km}$ cells included in the $0.5^{\circ} \times 0.5^{\circ}$ cell considered

\subsection{Constraint 4: other land-use function $\left(w_{i}\right)$}

The suitability of an area for wind turbine installation also depends on the current landuse function. This constraint is included using a suitability factor for land-use functions $\left(w_{i}\right)$ at grid cell level, defined as the fraction (between 0 and 1 ) of the land that is suitable for wind energy applications at a certain power density. The land-use and land-cover function as well as the data on bioreserves are taken from the IMAGE 2.2 database (IMAGEteam, 2001); the data are allocated to the whole grid cell, as is the factor $w_{i}$. It is assumed that with installed turbines, this part of the cell area will fulfil the same land-use function as before and no additional cost has to be made.

Siting constraints depend on land-use and land-cover functions; installing wind turbines in most cases means dual land use. This is best illustrated with agricultural land, where the installation of wind turbines can easily be combined with the production of vegetables or with keeping cattle (Pimentel et al., 1994). When wind turbines are planned, urban areas, bioreserves, lakes and other water bodies are often excluded (British Wind Energy Association, 2000; Elliot and Schwartz, 1993; EIA, 1999; Cabooter et al., 1997). Some studies have also investigated restrictions applicable to forest areas (EIA, 1999; National Wind Coordinating Committee, 1997; Elliot and Schwartz, 1993).

Elliot and Schwartz (1993) include in their assessment of the technical potential of wind energy in the USA three different scenarios for site exclusion. The environment scenario excludes only environmental areas designated as nature and wildlife parks. The severe scenario restricts the available area to $10 \%$ of rangeland. The so-called moderate or realistic scenario assumes that $90 \%$ of range and barren lands, $70 \%$ of the agricultural area and $50 \%$ of the forest area are available for wind turbine installation (Elliot and Schwartz, 1993).

We base our estimate of siting constraints on these studies (Table 1). High suitability factors are given to land-use and land-cover categories that facilitate dual use, and lower 
Table 1

Suitability factors and roughness lengths (see Section 5) that are assumed in this study for land-use categories

\begin{tabular}{|c|c|c|c|c|c|}
\hline \multirow{2}{*}{$\begin{array}{l}\text { Land-use category taken } \\
\text { from IMAGE } 2.2\end{array}$} & \multicolumn{4}{|c|}{ Suitability factor $(-)$} & \multirow[t]{2}{*}{ Roughness length $^{\mathrm{a}} z_{0}(\mathrm{~m}$} \\
\hline & This study & $\mathrm{UK}^{\mathrm{b}}$ & $\mathrm{USA}^{\mathrm{c}}$ & Belgium $^{\mathrm{d}}$ & \\
\hline Bioreserve $\left(b_{i}\right)$ & 0 & 0 & 0 & 0 & - \\
\hline Agricultural land $\left(w_{i}\right)$ & 0.7 & & $0-0.7$ & & 0.25 \\
\hline Extensive grassland $\left(w_{i}\right)$ & 0.8 & & $0.1-0.9$ & & 1 \\
\hline Forest (boreal) $\left(w_{i}\right)$ & 0.1 & & $0-0.5$ & & 1 \\
\hline Tropical forest $\left(w_{i}\right)$ & 0 & & & & 1 \\
\hline Tundra $\left(w_{i}\right)$ & 0.8 & & & & 0.25 \\
\hline Wooded tundra $\left(w_{i}\right)$ & 0.5 & & & & 0.25 \\
\hline Grassland/steppe $\left(w_{i}\right)$ & 0.8 & & $0.1-0.9$ & & 0.03 \\
\hline Hot desert $\left(w_{i}\right)$ & 1 & & & & 0.005 \\
\hline Shrubland $\left(w_{i}\right)$ & 0.5 & & & & 0.1 \\
\hline Savannah $\left(w_{i}\right)$ & 0.9 & & & & 0.25 \\
\hline
\end{tabular}

The roughness lengths are based on Wieringa and Rijkoort (1983) and Lysen (1982).

${ }^{\mathrm{a}}$ The roughness length as a function of the land-use category is used in Section 5.

${ }^{\mathrm{b}}$ British Wind Energy Association (2000).

${ }^{\mathrm{c}}$ Elliot and Schwartz (1993).

${ }^{\mathrm{d}}$ Cabooter et al. (1999).

factors or even zero to categories where this is not possible. Nature reserves are totally excluded $\left(b_{i}=0\right)$. Forest areas are categorised into tropical forests and nontropical forest (e.g., temperate, boreal). The former is excluded entirely, whereas $10 \%$ of other forest types are assumed to be available.

We have applied these restrictions to the grid cell data from the IMAGE 2.2 database. The regional average contribution of the constraints to the geographical potential is shown in Fig. 3. It can be seen that the constraint for the suitable wind regime is most severe; in some regions it even reduces the suitability factor to nearly zero (South East Asia and Southern and Western Africa). The USA, Canada and Oceania have the highest suitability factor $27 \%, 21 \%$ and $24 \%$, respectively. The global average value of $f_{i}$ of the total onshore area is $9 \%$.

\section{The technical potential}

\subsection{Approach}

The next step is to determine the technical potential, which is in this study the wind power that can be generated at the suitable area. The technical potential in a grid cell $i$ is expressed as:

$$
E_{i}=f_{i} A_{i} \eta_{\mathrm{a}} \eta_{\mathrm{ar}} D h_{\mathrm{f}, i}
$$

where $E_{i}$ is the wind energy output in grid cell $i\left(\mathrm{kWh} \mathrm{year}^{-1}\right), \eta_{\mathrm{a}}$ is the average availability of the wind turbine (-), $\eta_{\mathrm{ar}}$ is the wind farm array efficiency $(-), D$ is the power density (MW km${ }^{-2}$ ), and $h_{\mathrm{f}, i}$ is the full-load hours in grid cell $i(\mathrm{~h})$. Only the 


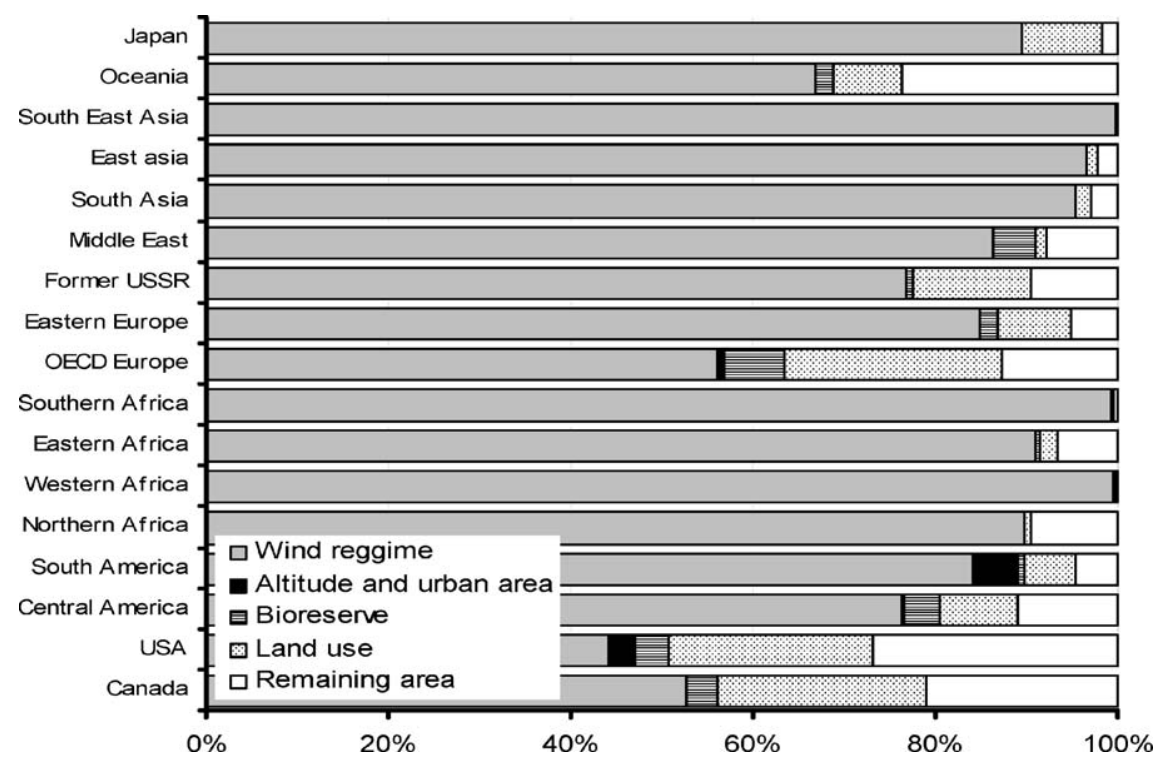

Fig. 3. The regional siting constraints, the remaining category equals the suitability factor $\left(f_{i}\right)$.

suitability factor $f_{i}$ (described above) and the full-load hours $h_{\mathrm{f}, i}$ differ at grid cell level. The global technical potential $E_{i}\left(\mathrm{kWh}_{\text {year }}{ }^{-1}\right)$ is expressed as the sum over all grid cells.

\subsection{Wind regime}

\subsubsection{Wind speed database}

We use the average monthly wind speed at grid cell level $\left(V_{10}\right)$ but have aggregated the results to annual averages. The wind speed data for cells are taken from the digital database at grid cell level $\left(0.5^{\circ} \times 0.5^{\circ}\right)$ constructed by the Climate Research Unit (CRU, New et al., 1997, 1999). ${ }^{6}$ The wind speed is presented in $\mathrm{m} \mathrm{s}^{-1}$ at a height of $10 \mathrm{~m}$. The data set is constructed from climatic average measured values (1961-1990) from 3615 stations, covering the world. The coverage of the stations is highest in Europe and lowest in Oceania (New et al., 1999). The original measured values come from national meteorological agencies and the World Meteorological Organisation (WMO). The data at grid cell level are constructed by interpolation of the measured data; uncertainties are not specified. $\mathrm{CRU}^{7}$ mentions errors in the data originating from the confusion of units, i.e., between metres per second and miles per hour and knots per hour. Furthermore, it was

6 The geographical coordinates of the wind speed data from CRU do not match completely with the grid cell definition of the IMAGE 2.2 database. The CRU database has been converted to the raster of the IMAGE 2.2 database from which all the land-use data are taken. Furthermore, differences existed in the definition of land cells vs. sea cells. This was the case for 4200 (border) grid cells. These data have been converted by means of linear interpolation. Cells that border the shore are included in this study if more than $10 \%$ is defined as land. We have included only the onshore area fraction in these cells.

7 All errors are mentioned on their web page http://ipcc-ddc.cru.uea.ac.uk/. 
mentioned that the anemometer heights can vary greatly from the desired $10 \mathrm{~m}$ (e.g., between 2 and $20 \mathrm{~m}$ ). Errors of these kinds are known to have occurred in Peru, Bolivia, Honduras, Sudan, Sierra Leone and Greece. In Latin America (Peru/Bolivia), unrealistic high values were found for the average wind speed (e.g., $25 \mathrm{~m} \mathrm{~s}^{-1}$ at $10 \mathrm{~m}$ ). These figures are not used. Instead, we have used a value adjusted to the neighbouring grid cells.

No digital databases or atlases providing monthly or annual average wind speed values at grid cell level for the world have been published. Therefore, a detailed comparison of our wind speed data with other studies could not be made. To explore the quality of the data, we have done a visual comparison with maps from the European wind atlas (Petersen et al., 1981), the wind atlas for the USA (Elliot et al., 1986), the wind atlas of India constructed by the Indian Institute of Tropical Meteorology (Rangarajan, 1998) and a wind atlas for South East Asia (Solutions, 2001). These comparisons show that the data are fairly consistent. Similar patterns are found and values are of the same order of magnitude; however, the figures from the CRU database seem to be slightly lower than those in the wind atlases. In particular, the comparison with the wind atlas of India (Rangarajan, 1998) showed that the wind speed data may regionally be rather low. While the CRU data give for India a regional annual average of $2.3 \mathrm{~m} \mathrm{~s}^{-1}$ at a height of $10 \mathrm{~m}$, Rangarajan (1998) gives the lowest value as $2.5 \mathrm{~m} \mathrm{~s}^{-1}$ at $10 \mathrm{~m}$.

\subsubsection{Extrapolation to hub height}

The wind speed $(v)$ changes with altitude because of frictional effects at the surface of the earth. Therefore, we have to correct for the wind speed at the presumed average hub height of the installed wind turbines. Assuming a stable situation and a measured wind speed at $10 \mathrm{~m}$, the average wind speed at height $H$ can be calculated according to e.g., Lysen (1982):

$$
v_{H}=V_{10}\left(\frac{\ln \left(H / z_{0}\right)}{\ln \left(10 / z_{0}\right)}\right)
$$

where $H$ is the height $(\mathrm{m}), v_{H}$ is the wind speed at $H\left(\mathrm{~m} \mathrm{~s}^{-1}\right)$, and $z_{0}$ is the roughness length of the surface $(\mathrm{m})$.

We adjust the average wind speed $V$ from the CRU database by estimating the roughness length $\left(z_{0}\right.$; Table 1$)$ using data on land cover and land use taken from the IMAGE 2.2 database (IMAGEteam, 2001). The hub height as part of the turbine design is a function of the wind regime, the rotor diameter and the rated power of the turbine. To obtain a generic relation, we have analysed the hub height as a function of the rated power for a number of turbines commercially available in Germany (Bundesverband WindEnergie, 1995-2000, 2001) in 2000. The data have been plotted as a function of the rated power $\left(P_{\mathrm{r}}\right.$; Fig. 4). A linear regression applied to these data yields the following empirically derived expression:

$$
H=C P_{\mathrm{r}}^{w}
$$

where $C$ and $w$ are constants at 10 and 0.28 , respectively. For the default turbine with a rated power $P_{\mathrm{r}}$ of $1000 \mathrm{~kW}$, a hub height of $69 \mathrm{~m}$ is found. 


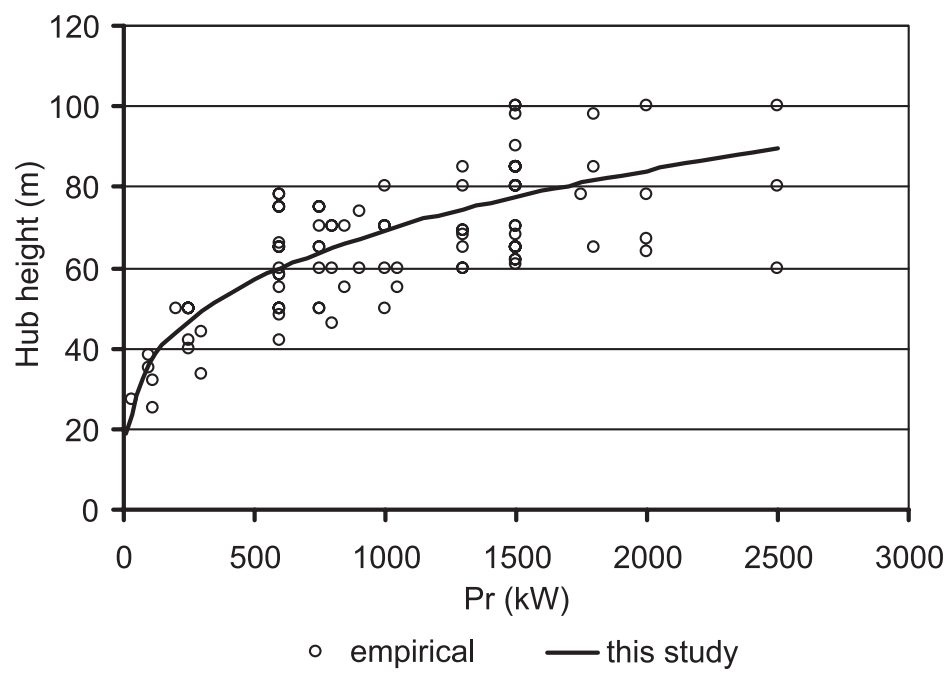

Fig. 4. The relation between the rated power of a wind turbine, $P_{\mathrm{r}}(\mathrm{kW})$, and the hub height $(\mathrm{m})$, as derived from data from existing wind turbines of the German market (Bundesverband WindEnergie, 1995-2000, 2001).

\subsection{Wind turbine output; amount of full-load hours}

The electricity output per turbine depends on the wind regime. In most regions, this can be described by a Weibull distribution function (see, e.g., Stevens and Smulders, 1979). ${ }^{8}$ The output also depends on the rated power of the wind turbine generator $\left(P_{\mathrm{r}}\right)$, the swept area (Ar) and the power curve of the turbine. Various combinations are possible between the generator and the rotor diameter, leading to different full-load hours $\left(h_{\mathrm{f}}\right)^{9}$ for the wind turbine. The aim is to achieve a cost-effective optimum, which is attained at full-load hours around $2000 \mathrm{~h}$ (BTM, 2001).

However, this optimum is attainable only if one can choose out of a large set of turbines for every type of wind regime. In reality, this is not the case. Only a restricted number of turbines are commercially available. We therefore follow a more realistic approach in which the turbine is not optimal for the wind regime. Data on the yearly output and the yearly average wind speed of various wind turbines at seven locations (wind farms; ${ }^{10}$ Windstats, 2000) show that there is a correlation between full-load hours and average wind speed (Fig. 5). The full-load hours vary between 05:50 and 34:00. Abed and ElMallah (1997) studied the capacity factor of wind turbines for several wind regimes. Their

8 The Weibull distribution function is a probability function of the form $f(v)=(k / a)(v / a)^{k-1} \exp (-v / a)^{k}$ in which $k$ is the Weibull shape factor (generally ranging between 1 and 3 ), $a$ is the scaling parameter, and $v$ is the wind speed.

9 Full-load hours are the number of hours a year that the wind turbine operates at rated power $\left(\mathrm{kWh} \mathrm{y}^{-1}\right.$ $\mathrm{kW}^{-1}$ ). The capacity factor (Cf) is defined as the ratio of the full-load hours and the total amount of hours in a year.

10 We have included reported output of wind farms that supplied all required information. The farms are situated in Belgium and the US. 


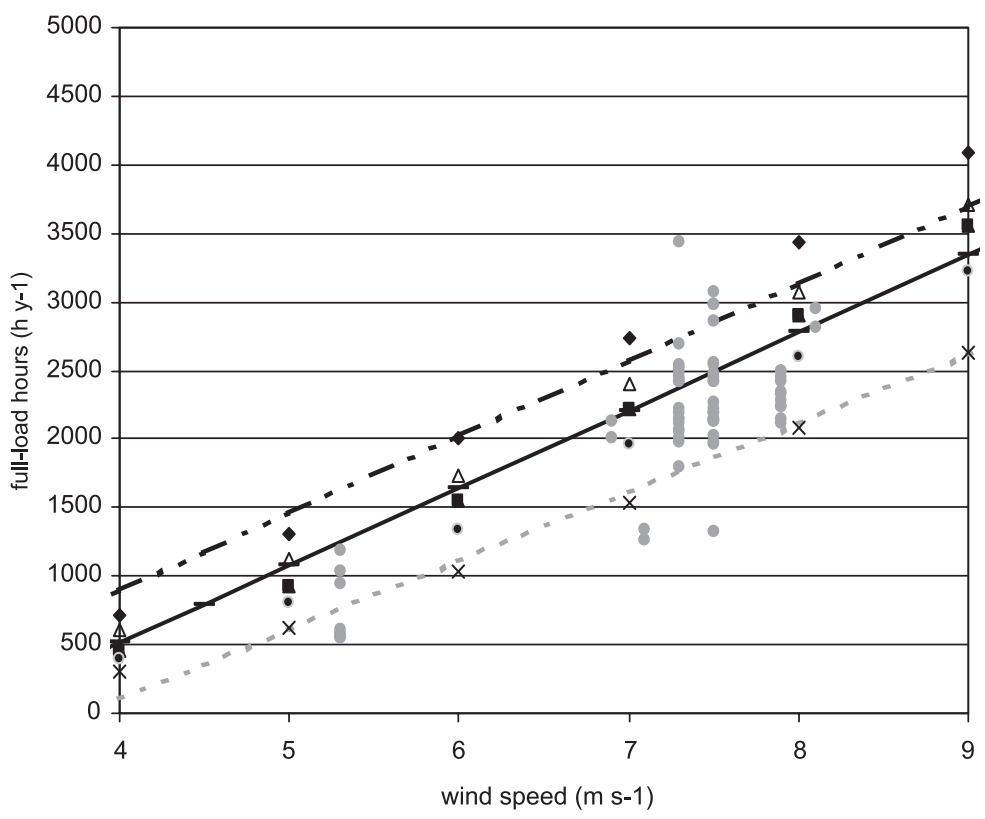

- Bonus 33.4

$\times$ Vestas V66 1650/66

- existing wind turbines
- NEG Micon $750 / 48$

- $\quad$ Wind world $750 / 48$

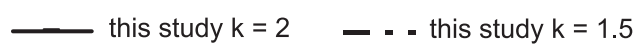

Fig. 5. The full-load hours as a function of the average annual wind speed for a set of seven commercially available turbines operating at various average wind speeds and Weibull factors $(k=1.5,2.0$ (default) and 3.0). Wind turbine output data of seven wind farms are included for comparison.

analysis results in a general mathematical expression for the full-load hours as a function of the cut-in and cut-out wind speed and rated wind speed as well as the Weibull parameters. We have simplified this expression to a linear relation determined by two factors, $\alpha_{1}$ and $\alpha_{2}$. These factors include information on the power curve and the Weibull parameters. The factors $\alpha_{1}$ and $\alpha_{2}$ are derived from theoretical performance of available wind turbines (Fig. 5). The full-load hours as a function of the average annual wind speed are calculated using a Weibull distribution and the power curve of six commercially available wind turbines (adapted from Danish Wind Turbine Manufactures Association). We have assumed the maximum full-load hours at 4000 for the present situation.

$$
h_{\mathrm{f}, i}=\alpha_{1} V_{h, i}-\alpha_{2}
$$

where $h_{\mathrm{f}, i}$ is the amount of full-load hours in grid cell $i$. The value of $\alpha_{1}$ is found at $565 \mathrm{~s}$ $\mathrm{h}^{-1} \mathrm{~m}^{-1}$ year ${ }^{-1}$ and $\alpha_{2}$ at $1745 \mathrm{kWh} \mathrm{kW}^{-1}$ year $^{-1}$ for the Weibull function with $k=2$. The relation taken in this study $(k=2)$ lies within the range of the empirical data supplied although the latter seem to be slightly lower (Fig. 5). 


\subsection{Wind power density per $\mathrm{km}^{2}$}

From the output of a turbine, we move on to the potential output of wind turbines in a grid cell. The available area per grid cell has been determined in the previous section. For the assessment of the specific energy output in the grid cell, the power density $\left(D_{i}\right)$ is a crucial variable. We introduce the power density in the suitable area:

$$
D_{i}=N_{\mathrm{t}, i} P_{\mathrm{r}}
$$

where $D_{i}$ is the average installed power density $\left(\mathrm{kW} \mathrm{km}^{-2}\right)$ in the grid cell at the suitable area, $N_{\mathrm{t}, i}$ is the number of turbines per $\mathrm{km}^{2}$ in grid cell $i$, and $P_{\mathrm{r}}$ is the average rated power of a turbine with a default value of $1000 \mathrm{~kW}$.

The literature reports current values for power densities at wind farm level varying from around $17 \mathrm{MW} \mathrm{km}{ }^{-2}$ for dense arrays in California to 5-8 $\mathrm{MW} \mathrm{km}^{-2}$ for European wind farms (ABB, 1998). The power density of a wind farm is determined by various factors, e.g., the infrastructure required for the turbines, the acceptable losses from interference, the available area and even visual constraints (not included in this study). Similar constraints are valid for the suitable area in a grid cell. However, we cannot quantify one of these constraints or considerations at this level of detail. Therefore, as an upper level, we argue that the power density at the suitable area in a grid cell is just below the value of a wind farm at a level of $4 \mathrm{MW} \mathrm{km}^{-2}$. This figure includes the reduction of the power density because of the installation of single turbines instead of wind farms, e.g., in the year 2000, only 53\% of the installed wind turbines were located in wind farms (BTM, 2001).

Assuming a power density of $4 \mathrm{MW} \mathrm{km}^{-2}$ in the suitable area in a grid cell, we get an upper limit for the technical potential at grid cell level, since power density values at national or provincial level are at present below $4 \mathrm{MW} \mathrm{km}^{-2}$ as shown in Table 2. At the national level, the highest power densities are found in Denmark, namely, 0.05 MW $\mathrm{km}^{-2}$. At provincial level, Schleswig-Holstein has the highest power density, 0.09 MW $\mathrm{km}^{-2}$. For correct comparisons, we have estimated the country or regionally average suitability factor based on the land-use, land-cover, and altitude and wind speed data used in this study. This resulted in an estimate of the power density at the suitable area as is

Table 2

Power densities in a suitable area calculated using the country average suitability factor derived from this study

\begin{tabular}{lllll}
\hline Country/region & $\begin{array}{l}\text { Installed capacity } \\
\text { in MW (2001) }\end{array}$ & $\begin{array}{l}\text { Power density } \\
\left(\mathrm{MW} \mathrm{km}^{-2}\right)\end{array}$ & $\begin{array}{l}\text { Average suitability } \\
\text { factor (derived } \\
\text { from this study) }\end{array}$ & $\begin{array}{l}\text { Power density at } \\
\text { suitable area } \\
\left(\mathrm{MW} \mathrm{km}^{-2}\right)\end{array}$ \\
\hline $\begin{array}{l}\text { Denmark } \\
\text { Germany }\end{array}$ & 2297 & 0.05 & 0.2 & 0.27 \\
$\begin{array}{l}\text { Schleswig-Holstein } \\
\quad 6113\end{array}$ & 1342 & 0.02 & 0.15 & 0.12 \\
$\quad$ Germany) & 0.09 & 0.3 & 0.28 \\
The Netherlands & 448 & 0.01 & 0.1 & 0.13 \\
The Netherlands-target & $1500^{\mathrm{a}}$ & 0.04 & 0.1 & 0.44 \\
\hline
\end{tabular}

The power density at the suitable area can be compared with the power density used in this study.

${ }^{\text {a }}$ This is the national onshore target for 2020 . 
shown in Table 2. This value corresponds to the power density assumed in this study. The highest power density in a suitable area $\left(0.28 \mathrm{MW} \mathrm{km}^{-2}\right.$ for Schleswig-Holstein) is still far below the value of $4 \mathrm{MW} \mathrm{km}^{-2}$ assumed in this study.

Eq. (3) also introduces two efficiency factors. The availability factor $\left(\eta_{\mathrm{a}}\right)$ is the fraction of the full-load hours in a year that the wind turbine is actually available and is set at 0.95 (allowing for repair, breakdowns etc.). This is a low value in view of literature values up to 0.98 (Neij, 1999; Chapman and Wise, 1998). However, as a global average, it is assumed to be realistic, since we also include several regions with less experience at present.

The array efficiency $\left(\eta_{\mathrm{ar}}\right)$ is the efficiency of a total wind farm which decreases with closer spacing due to the interference of wind turbines. Its value is a function of the turbine spacing, configuration and size of wind farms. Indicative empirically derived values in the literature vary between 0.49 and 0.96 (Grubb and Meyer, 1993); 0.49 for high-density (a matrix of $10 \times 10$ and a spacing of $4 \times$ diameter) and 0.96 for low-density (a matrix of $4 \times 4$ and a spacing of $10 \times$ diameter) wind farms. We assume a fixed array efficiency of 0.90. Using the array efficiency values supplied by Grubb and Meyer (1993), 0.90 is consistent with a power density of $4 \mathrm{MW} \mathrm{km}^{-2}$, a $P_{\mathrm{r}}$ of $1000 \mathrm{~kW}$ and a $2 \times 2$ matrix placing with a spacing 5 times the turbine diameter.

\subsection{Results}

A large number of grid cells have no technical potential, due to a suitability factor of 0 . The highest figure for the technical potential in a grid cell is calculated at $55 \mathrm{TWh}$ year $^{-1}$. We have ranked the technical potential $E_{i}$ (Eq. (3) for all cells (Fig. 6). It is

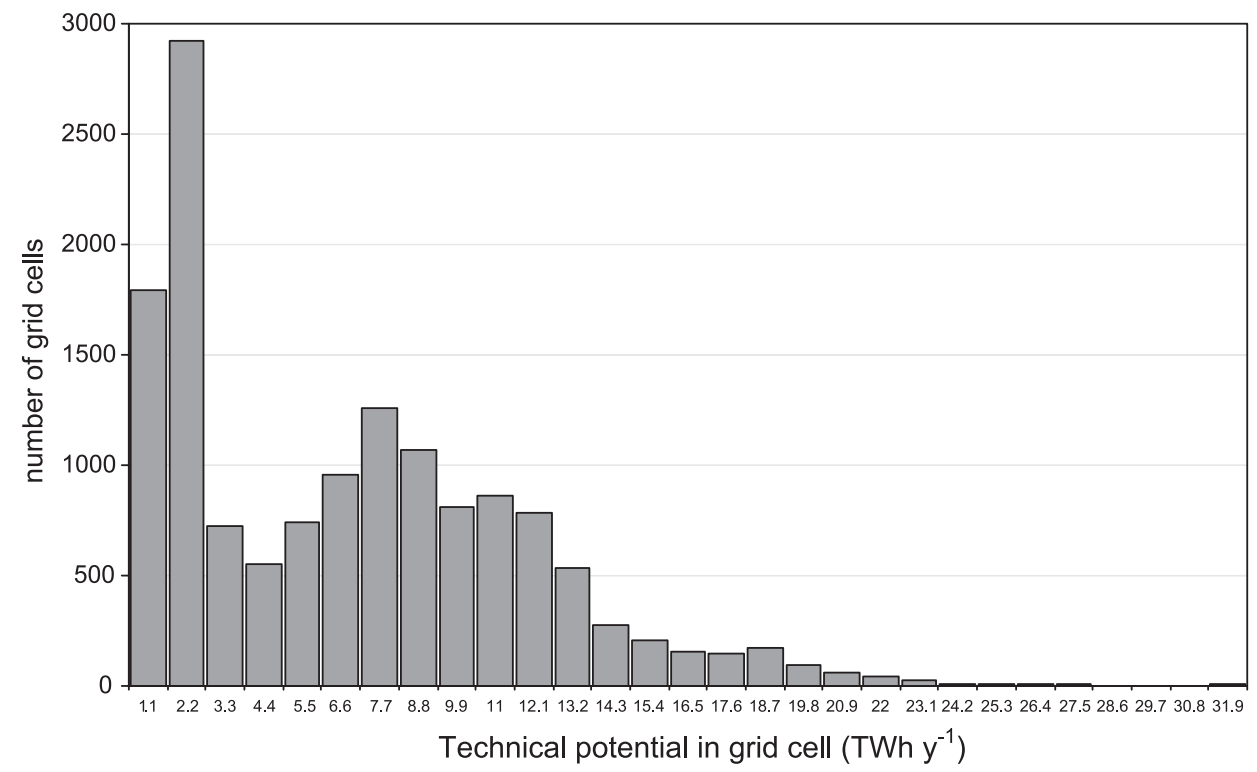

Fig. 6. The global distribution of the technical potential over the grid cells as calculated in this study (N.B. 17 cells exceed $30 \mathrm{TWh}_{\text {year }}{ }^{-1}$ ). 
Table 3

The regional distribution of the area, suitable area, regional average wind speed, technical potential and technical potential at three different cut-off costs

\begin{tabular}{|c|c|c|c|c|c|c|c|c|}
\hline & $\begin{array}{l}\text { Area } \\
\text { (Mha) }\end{array}$ & $\begin{array}{l}\text { Suitable } \\
\text { area (Mha) }\end{array}$ & $\begin{array}{l}\text { Average wind } \\
\text { speed }\left(\mathrm{m} \mathrm{s}^{-1}\right)\end{array}$ & $\begin{array}{l}\text { Average power } \\
\text { density } \\
\left(\mathrm{MW} \mathrm{km}^{-2}\right)\end{array}$ & $\begin{array}{l}\text { Technical potential } \\
\left(\mathrm{PWh} \mathrm{year}^{-1}\right)\end{array}$ & $\begin{array}{l}\text { Technical potential } \\
\text { cut-off } 0.07 \\
\text { US\$ kWh } \\
(\mathrm{PWh} \text { year } \\
\end{array}$ & $\begin{array}{l}\text { Technical potential } \\
\text { cut-off } 0.10 \\
\text { US\$ kWh } \\
\left(\mathrm{PWh} \text { year }^{-1}\right)\end{array}$ & $\begin{array}{l}\text { Ratio technical potential } \\
\text { and present electricity } \\
\text { consumption }^{\mathrm{a}}\end{array}$ \\
\hline Canada & 950 & 199 & 4.1 & 1.08 & 19 & 8 & 16 & 32.7 \\
\hline USA & 925 & 248 & 4.3 & 1.02 & 21 & 3 & 13 & 5.6 \\
\hline Central America & 269 & 29 & 3.3 & 0.40 & 2 & 1 & 1 & 10.5 \\
\hline South America & 1,761 & 82 & 3.0 & 0.26 & 8 & 4 & 6 & 13.0 \\
\hline North Africa & 574 & 55 & 2.9 & 0.42 & 3 & 0.00 & 0.04 & 23.3 \\
\hline West Africa & 1,127 & 4 & 1.8 & 0.01 & 0.2 & 0.00 & 0.04 & 5.7 \\
\hline East Africa & 583 & 38 & 2.6 & 0.28 & 3 & 0.00 & 0.23 & 358.3 \\
\hline South Africa & 676 & 3 & 2.2 & 0.03 & 0.2 & 0.00 & 0.00 & 1.0 \\
\hline Western Europe & 372 & 47 & 4.3 & 0.58 & 4 & 1 & 2 & 1.6 \\
\hline Eastern Europe & 116 & 6 & 3.1 & 0.22 & 0.4 & 0.01 & 0.1 & 1.0 \\
\hline Former USSR & 2,183 & 206 & 3.4 & 0.47 & 16 & 2 & 7 & 12.6 \\
\hline Middle East & 592 & 47 & 3.1 & 0.33 & 2 & 0.00 & 0.00 & 5.6 \\
\hline South Asia & 509 & 15 & 2.3 & 0.12 & 1 & 0.00 & 0.00 & 1.9 \\
\hline East Asia & 1,108 & 25 & 2.4 & 0.10 & 2 & 0.00 & 0.05 & 1.1 \\
\hline South East Asia & 442 & 0 & 2.0 & 0.01 & 0.03 & 0.00 & 0.00 & 0.1 \\
\hline Oceania & 838 & 199 & 3.6 & 0.91 & 14 & 1 & 6 & 68.5 \\
\hline Japan & 37 & 1 & 3.3 & 0.08 & 0.1 & 0.00 & 0.01 & 0.1 \\
\hline Global & 13,063 & 1123 & 3.0 & 0.37 & 96 & 21 & 53 & 7.0 \\
\hline
\end{tabular}

${ }^{a}$ We use the IEA data of 1996 on the present electricity consumption at a regional level for this ratio as these were available at the same regional aggregation. These data are, however, lower than present consumption data. 
shown that most grid cells have a technical potential around 2-3 $\mathrm{TWh}_{\text {year }}{ }^{-1}$. The global technical potential is calculated by summing over all grid cells (surface under the curve in Fig. 6). It is estimated to be $96 \mathrm{PWh}_{\text {year }}{ }^{-1}$, about 6-7 times the present (2001) electricity consumption of $15 \mathrm{PWh}_{\text {year }}^{-1}$ (BP, 2001). The regional technical potential is calculated by summing over all grid cells by region. High values are found in the USA, the former USSR and Oceania. The regional results are summarised in Table 3.

The highest regional technical potential is found in the USA, with a large suitable area and a relatively high average wind speed.

\section{The cost of wind electricity: the economic potential using regional cost-supply curves}

\subsection{Approach}

The economic potential is defined as the amount of wind electricity that can be generated at costs that are competitive with other electricity sources. In this study, we construct the cost-supply curves for wind electricity, which is a ranking of the technical potential in the grid cells according to the wind electricity costs in the grid cells. For this purpose, we calculate the electricity production costs for all grid cells. We annuitize ${ }^{11}$ the total investment costs $I$ and the annual O\&M costs in a grid cell and divide it by its annual output:

$$
\mathrm{Coe}_{i}=\frac{\gamma(1+\varepsilon) I D}{E_{i}}
$$

where $\mathrm{Coe}_{i}$ is the production cost of electricity in grid cell $i$ (US\$ $\mathrm{kWh}^{-1}$ ), $\gamma$ is the annuity factor $(-)$, and $\varepsilon$ is the cost of operation and maintenance, defined as fraction of investment cost, but included in annuity.

The annual O\&M costs are taken to be constant and scale-independent at a fixed fraction of the capital costs $(\varepsilon=0.03)$. We neglect that the O\&M costs tend to increase over time (Lemming et al., 1999).

The investment cost $I$ is determined by the specific turbine investment costs $\left(I_{\mathrm{t}}\right)$ and other costs such as foundation and grid connection costs. Several studies show that the turbine costs are about $80 \%$ of the total investment costs (Morthorst, 1998; Rehfeldt et al., 1997; Laali et al., 1996; Lemming et al., 1999). Hence, the total specific investment costs are expressed as:

$$
I=\frac{I_{\mathrm{t}}}{\zeta}
$$

where $\zeta$ is the fraction of turbine costs in the total.

\footnotetext{
11 Annuitizing is done in the usual way: $\gamma=r /\left[1-(1+r)^{-L}\right]$ where $r$ is the interest rate set at $10 \%$ and $L$ is the economic lifetime set at 20 years.
} 
The specific turbine investment costs are assumed to be a function of the scale of the turbine using a defined reference turbine as basis:

$$
\frac{I_{\mathrm{t}}}{I_{\mathrm{t} 0}}=\left(\frac{P_{\mathrm{r}}}{P_{\mathrm{r} 0}}\right)^{\beta}
$$

where $I_{\mathrm{t}}$ is the specific investment cost of the turbine (US\$ $\left.\mathrm{kW}^{-1}\right), I_{\mathrm{t} 0}$ is the specific investment cost of a defined reference turbine (US\$ $\mathrm{kW}^{-1}$ ), $P_{\mathrm{r} 0}$ is the capacity of the defined reference turbine $(\mathrm{kW})$, and $\beta$ is the scaling factor $(-)(\beta<0)$.

The reference turbine has a power of $800 \mathrm{~kW}\left(P_{\mathrm{r} 0}\right)$ specific investment cost of 1000 US\$ $\mathrm{kW}^{-1}\left(I_{\mathrm{t} 0}\right)$. The parameter $\beta$ is derived from a set of historical data from German industry (Bundesverband WindEnergie, 1995-2000). For 1995-1998, it varies between -0.29 and -0.32 (although with a large spread: $0.58<R^{2}<0.77$ ). We use $\beta=-0.3$. This relation is used in the sensitivity analysis to investigate the impact of larger turbine sizes.

\subsection{Results}

For each cell, we have calculated the generation costs using reference turbine data and grid cell technical potential (Eq. (8)). The cells in which wind electricity can be generated at costs below $0.06,0.10,0.15$ and $0.25 \mathrm{USS}_{\mathrm{kWh}}^{-1}$ are shown in Fig. 7.

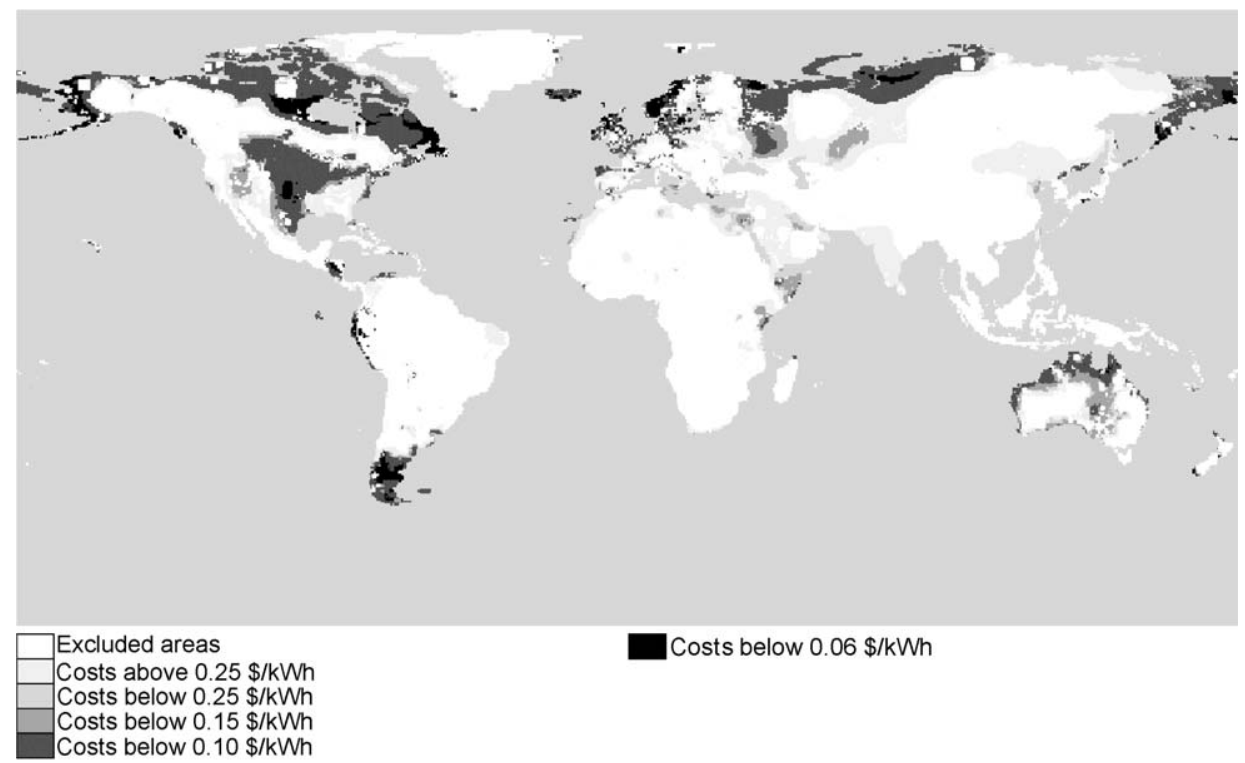

Fig. 7. The areas where wind electricity can be generated at various cost classes (costs below $0.20,0.15,0.10$ and

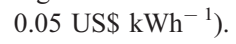



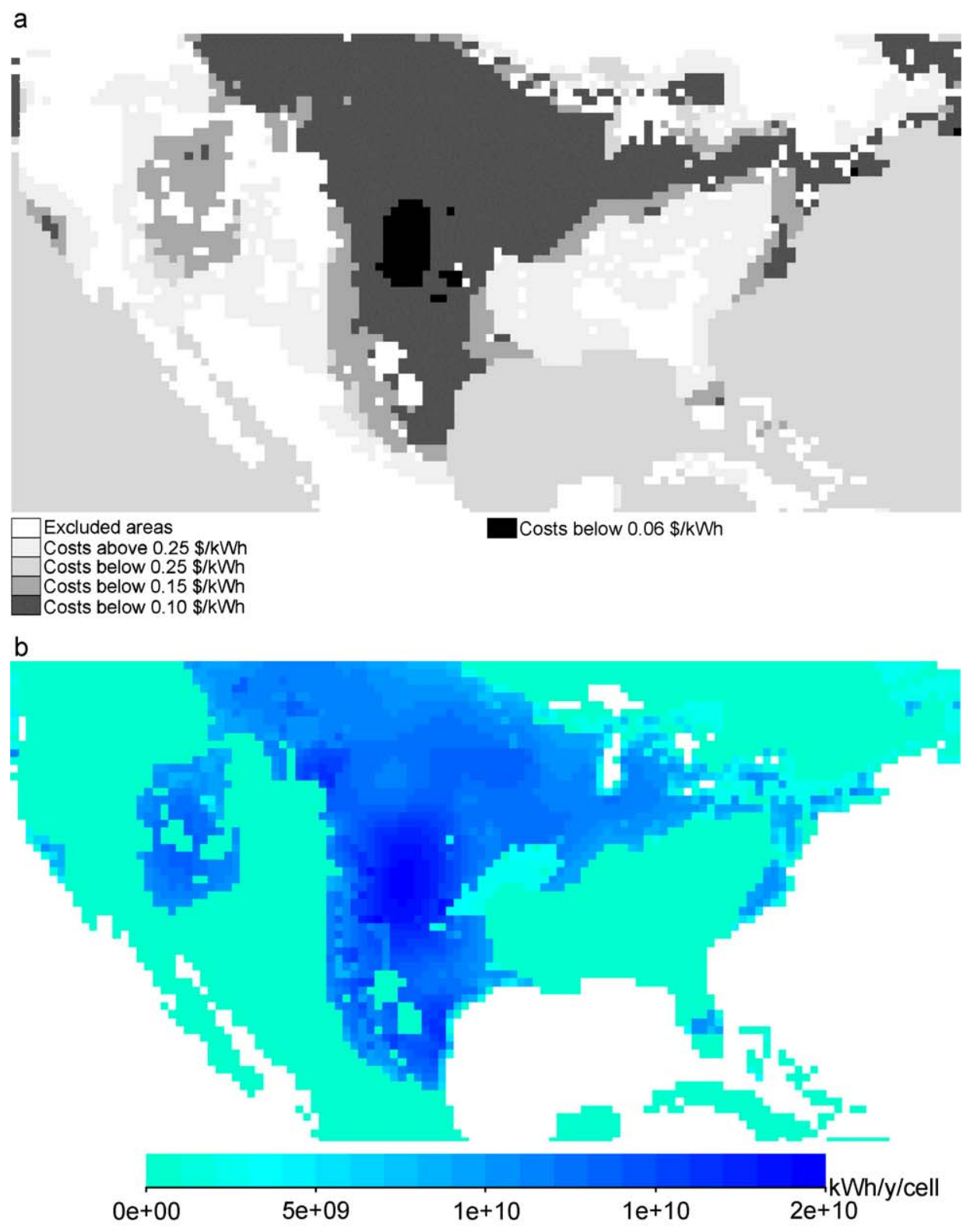

Fig. 8. (a) The areas in the USA where wind electricity can be generated at costs below $0.25,0.15,0.10$ and 0.06 US\$ $\mathrm{kWh}^{-1}$. (b) The technical potential per grid cells for the USA in $\mathrm{kWh}_{\text {year }}{ }^{-1}$. 
The lowest calculated cost of wind electricity in a grid cell is $0.05 \mathrm{USS} \mathrm{kWh}^{-1}$ (see Fig. 10). Wind speed found at these cells have values of around $8 \mathrm{~m} \mathrm{~s}^{-1}$. We consider our results consistent with values found in the literature, as literature on the current costs of

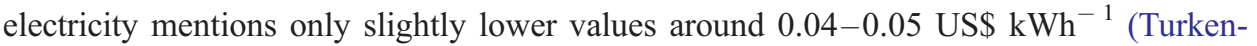
burg, 2000; Morthorst, 1998).

To provide insight into the amount of electricity that can be generated using wind power at certain costs, we combine the cost information with estimates of the technical potential. This is illustrated for the USA in Fig. 8a and b. USA is taken as an example as it has the highest regional technical onshore wind electricity potential. There is a clear correspondence between high grid cell potential (Fig. 8b) and low production cost (Fig. 8b). A large amount (13 $\mathrm{PWh}_{\text {year }}{ }^{-1}$ ) of wind energy can be generated at costs below $0.10 \mathrm{US} \$ \mathrm{kWh}^{-1}$. This amount corresponds with nearly the present (2001) electricity consumption in the USA (BP, 2001). Largest share is found in the Great Plains, which is consistent with resource assessments at national scale (Elliot and Schwartz, 1993; National Wind Coordinating Committee, 1997; AWEA, 2000). At present, the wind energy turbines are installed rapidly in these areas (AWEA, 2000).

The regional cost-supply curves of the six regions with high technical potential and/or low cost are shown in Fig. 9. Also included is the global cost-supply curve and the present world electricity production and price range (BP, 2001; Goldemberg,

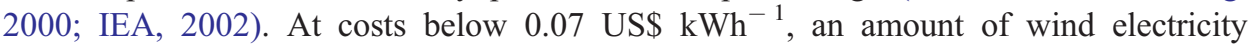
can be generated at the level of the present (2001) world electricity production (see Fig. 9). This is still high compared to the present average electricity costs around 0.04 US\$ $\mathrm{kWh}^{-1}$; however, due to variations in the conventional electricity

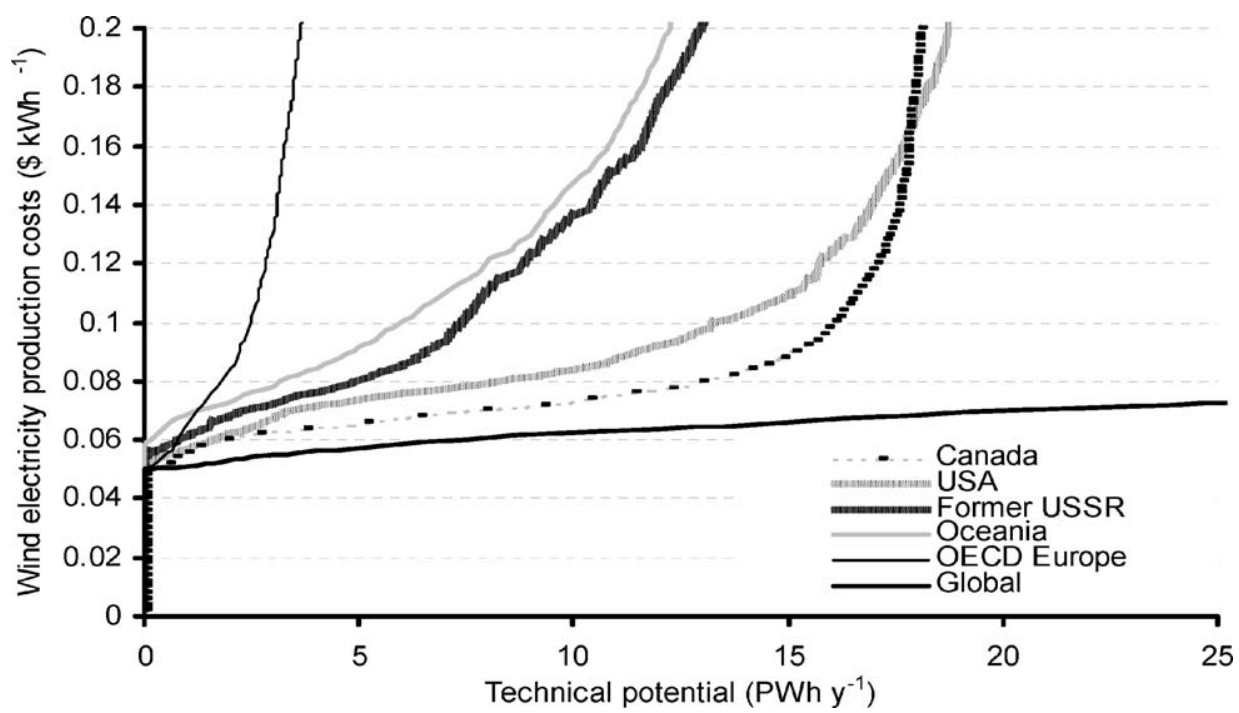

Fig. 9. Regional cost-supply curve for wind energy (US\$ $\mathrm{kWh}^{-1}$ vs. PWh year ${ }^{-1}$ ) for $D=4 \mathrm{MW} \mathrm{km}^{-2}$. For comparison, the global cumulative curve is also presented. 
production cost, the wind energy production does fall in the range (IEA, 2002; Goldemberg, 2000).

\section{Discussion of the results}

We study the results in more detail in two ways: a one-factor sensitivity analysis and a comparison with results from previous studies.

\subsection{Sensitivity analysis}

A sensitivity analysis aims to give insight into the sensitivity of the output (technical potential and cost-supply curves) to the value of the input parameters. The accuracy of the input parameters used range from high (strong) to low (weak). 'Weak' knowledge (and in here 'weak' parameters) is knowledge that is tied to personal and social values and cannot be measured under controlled conditions. 'Strong' knowledge (and so 'strong' parameters) is knowledge that is empirically measurable and controllable; we consider a parameter fair if it is estimated or calculated from measurable values. In this study, we consider the power density and the land-use suitability factor as 'weak' parameters. If wind turbines are installed, the power density can be measured. However, the maximum power density that is required for the technical potential is not measurable since it is a function of various social factors. Similar arguments apply for the suitability factors. The share of the agricultural land that can be used for wind turbine installation is among others a function of the value given to wind energy; that is, it has a high priority with respect to other land-use options. It is hard to define absolute ranges for these 'weak' parameters. Therefore, we first perform the sensitivity analysis of the 'strong' parameters before studying the sensitivity of the power density and the suitability factor.

The accuracy of the $V_{10}$ database is subject for discussion. As mentioned before, the variation with empirical values could not be quantified, nor could the range of variation. For the sensitivity analyses, we have multiplied the default $V_{10}$ with $0.75-1.25$ in line with the earlier observations. The range of $\eta_{\mathrm{ar}}$ and $\eta_{\mathrm{a}}$ is restricted by the upper limit at 1 ; at the lower limit, a reduction of $25 \%$ is assumed, as lower efficiencies are barely mentioned in the literature. The same can be said for the rated power $\left(P_{\mathrm{r}}\right)$. Currently installed wind turbines vary from $300 \mathrm{~kW}$ to $2 \mathrm{MW}$ (Ackermann and Soeder, 2002). This range is used in the sensitivity analysis although, in the future the rated power might increase even further. A range is found in the literature for the scaling factor $\beta$ (see Section 6). However, we have taken a broader range of $25 \%$ higher and lower since the empirical basis is too weak for us to consider the ranges found as absolute ranges. For the operational and maintenance costs defined as a fraction of investment costs, the ranges found in the literature are used. The variation in input parameters is summarised in Table 4.

The sensitivity analysis with these strong parameters is not complex as most relationships are linear (see also the complete equation in Appendix A). Fig. 10 and Table 4 show the sensitivity of the technical potential for $\eta_{\mathrm{a}}, \eta_{\mathrm{ar}}, P_{\mathrm{r}}, \beta, \varepsilon$, and $V_{10}$. As 
Table 4

The variation of the input parameters used in the sensitivity analysis and the variation in the results of the technical potential and the lowest cost

\begin{tabular}{lllll}
\hline Parameter & $\begin{array}{l}\text { Range } \\
\text { relative }\end{array}$ & $\begin{array}{l}\text { Range } \\
\text { absolute }\end{array}$ & $\begin{array}{l}\text { Range in technical } \\
\text { potential }\left(\mathrm{PWh} \mathrm{year}^{-1}\right)\end{array}$ & $\begin{array}{l}\text { Lowest cost } \\
\left(\mathrm{US}_{\phi} \mathrm{kWh}^{-1}\right)\end{array}$ \\
\hline$V_{10}$ & $0.75-1.25$ & & $19-210$ & $5.2-5.2^{\mathrm{a}}$ \\
$P_{\mathrm{r}}$ & $0.33-2.0$ & $300-2000 \mathrm{~kW}$ & $87-101$ & $4.2-7.4$ \\
$\eta_{\mathrm{ar}}$ & $0.75-1.10$ & $0.675-0.99$ & $69-105$ & $4.6-6.8$ \\
$\eta_{\mathrm{a}}$ & $0.75-1.05$ & $0.71-0.99$ & $72-101$ & $5.0-6.8$ \\
$\beta$ & $0.75-1.25$ & -0.23 to -0.38 & & $5.0-5.2$ \\
$\varepsilon$ & $0.33-1.66$ & $0.01-0.05 \%$ & & $4.4-5.8$ \\
\hline
\end{tabular}

${ }^{a}$ There is no variation in lowest costs as we assumed an upper limit of the full-load hours.

expected, the technical potential is highly influenced by the average monthly wind speed [see also Eq. (3)]. The discontinuity shown in Fig. 10 is the result from the cut-off wind speed at $4 \mathrm{~m} \mathrm{~s}^{-1}$ at a height of $10 \mathrm{~m}$. A $25 \%$ increase in wind speed more than doubles the technical potential. Due to restriction of wind resources at $4.0 \mathrm{~m} \mathrm{~s}^{-1}$ at a height of $10 \mathrm{~m}$, a $25 \%$ reduction of the wind speed is even more significant; the technical potential is reduced to $19 \%$. The technical potential is only slightly sensitive to $\eta_{\mathrm{ar}}$ and $\eta_{\mathrm{a}}$, and barely to $P_{\mathrm{r}}$. It is understandable that an increase in $P_{\mathrm{r}}$ contributes only

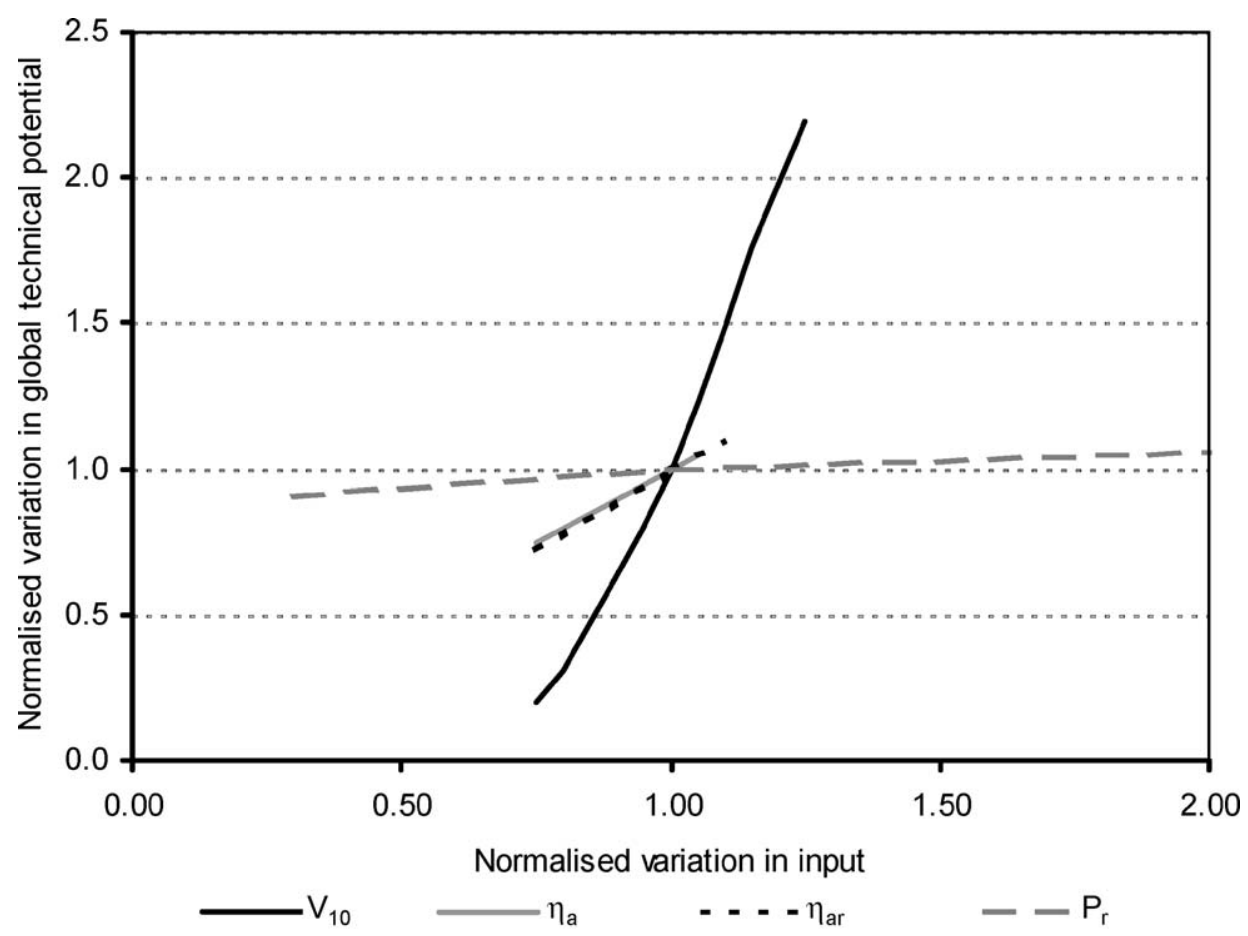

Fig. 10. Sensitivity of five input parameters $\left(\eta_{\mathrm{ar}}, \eta_{\mathrm{a}}, P_{\mathrm{r}}\right.$ and $\left.V_{10}\right)$ to the total technical potential. The variation of the parameters and the output is normalised to the default setting. 
marginally, since the power density is fixed in this study and thus the $P_{\mathrm{r}}$ only influences the hub height [see Eqs. (4) and (5)].

The cost-supply curve is also highly sensitive to the annual average wind speed at $10 \mathrm{~m}$ (see Fig. 11), as well as to the rated power $\left(P_{\mathrm{r}}\right)$. The electricity output per turbine increases due to an increase in nominal power and thus in hub height. Furthermore, as a result of the scaling factor, the specific investment costs are reduced [see Eq. (10)].

The parameters that are considered to be more weakly underpinned, namely, the power density and the land-use suitability factors, are studied separately. These parameters have a high impact on the results, as summarised in Fig. 12. It shows the four extreme cost-supply curves for extreme values of land-use suitability factors (the values presented in Table 1 are default, low is $25 \%$ lower and high is $25 \%$ higher). The power density ranges from $0.1 \mathrm{MW} \mathrm{km}^{-2}$ in suitable area such as those found currently in the Netherlands and Germany (see Table 2) to $8 \mathrm{MW} \mathrm{km}^{-2}$ in suitable areas, equal to wind farm values. The top right corner of Fig. 12 shows the cost-supply curve with high power density and high land-use suitability factors. The lowest graph on the left shows the cost-supply curve for the low power density and land-use suitability factor. This can be considered as a 'worst case'.
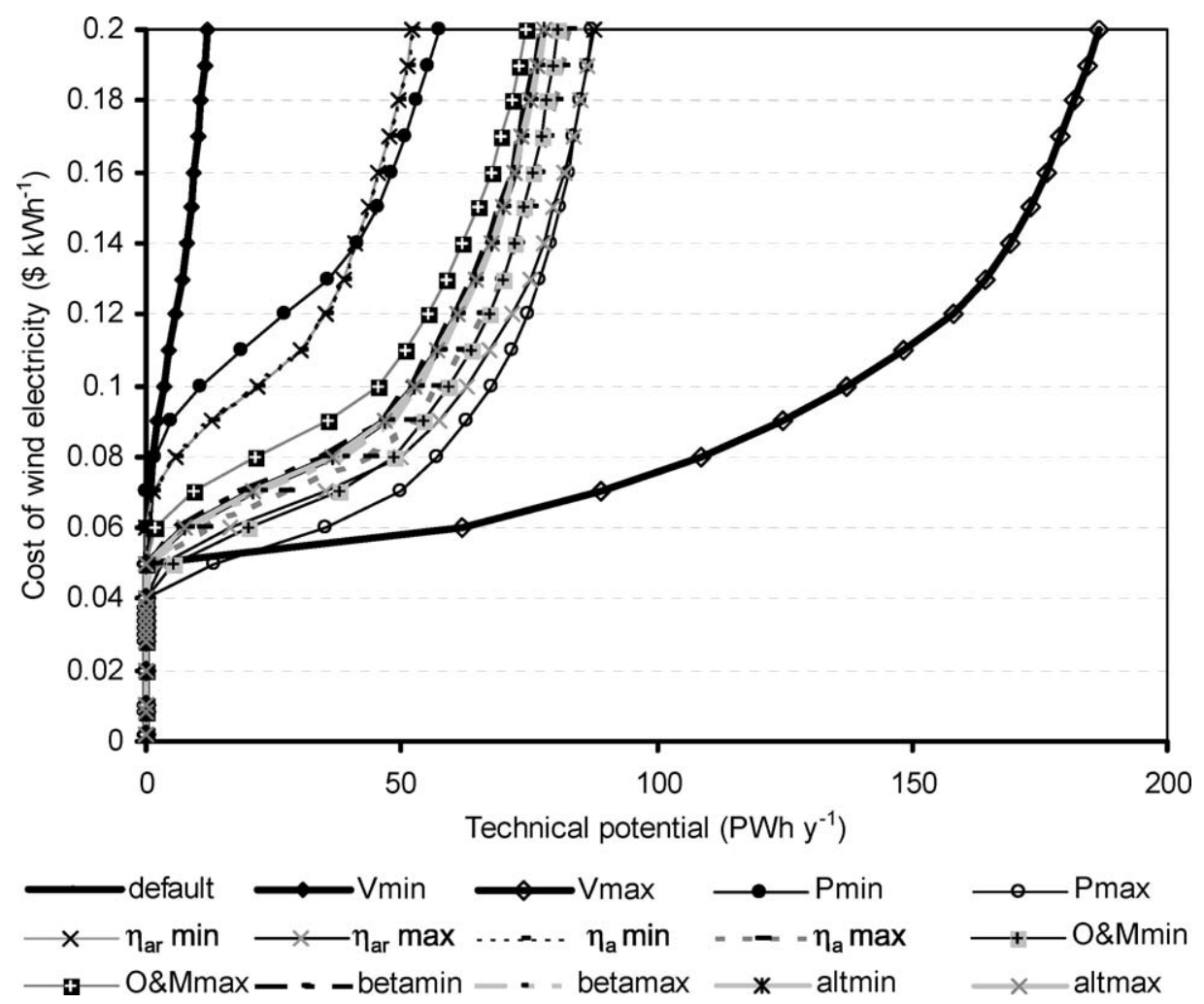

Fig. 11. Sensitivity of input parameters $\left(\eta_{\mathrm{ar}}, \eta_{\mathrm{a}}, P_{\mathrm{r}}, \varepsilon, \beta\right.$ and $\left.V_{10}\right)$ on the global cost-supply curve. 


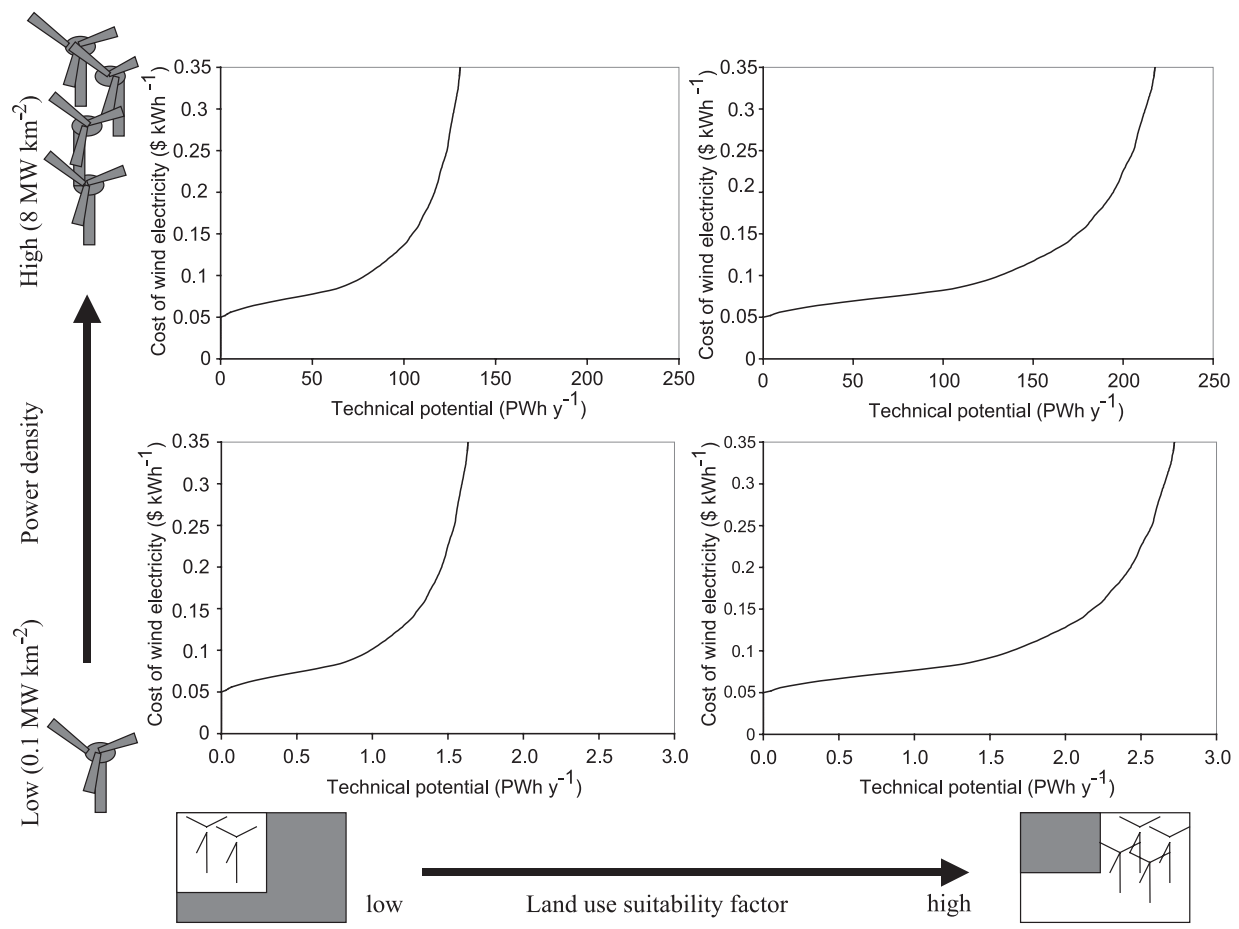

Fig. 12. The wind electricity cost-supply curve for four extreme situations. The 'weakly' known parameters $D$ and $w_{i}$ are varied over a broad range, notice differences in scale.

\subsection{Comparison with previous studies}

We have compared the results of the onshore technical potential in detail with three previous studies:

1. the study by Grubb and Meyer (1993);

2. the WEC study conducted by Utrecht University (World Energy Council, 1994);

3. the IEA/OECD (2000) study conducted by Garrad and Hassan (Fellows, 2000).

All studies assess the global and regional technical potential including site constraints.

The results of the global onshore technical potential of wind energy vary widely, from $19 \mathrm{PWh}_{\text {year }^{-1}}$ as simulated by the WEC study (World Energy Council, 1994) to 53 PWh year $^{-1}$ as given by Grubb and Meyer (1993). The IEA/OECD study presents a value of 37 PWh year ${ }^{-1}$ (Fig. 13). The estimated wind energy potentials vary widely over the regions. This study finds relatively higher values for all regions except for Central Asia, West Europe and Africa (see Fig. 13).

The differences are caused by differences in the input parameters (e.g., wind speed, power density) and main assumptions (cut-off wind speed, land-use constraints). Some of the input parameters are difficult to compare, e.g., wind resource. However, to make a better 


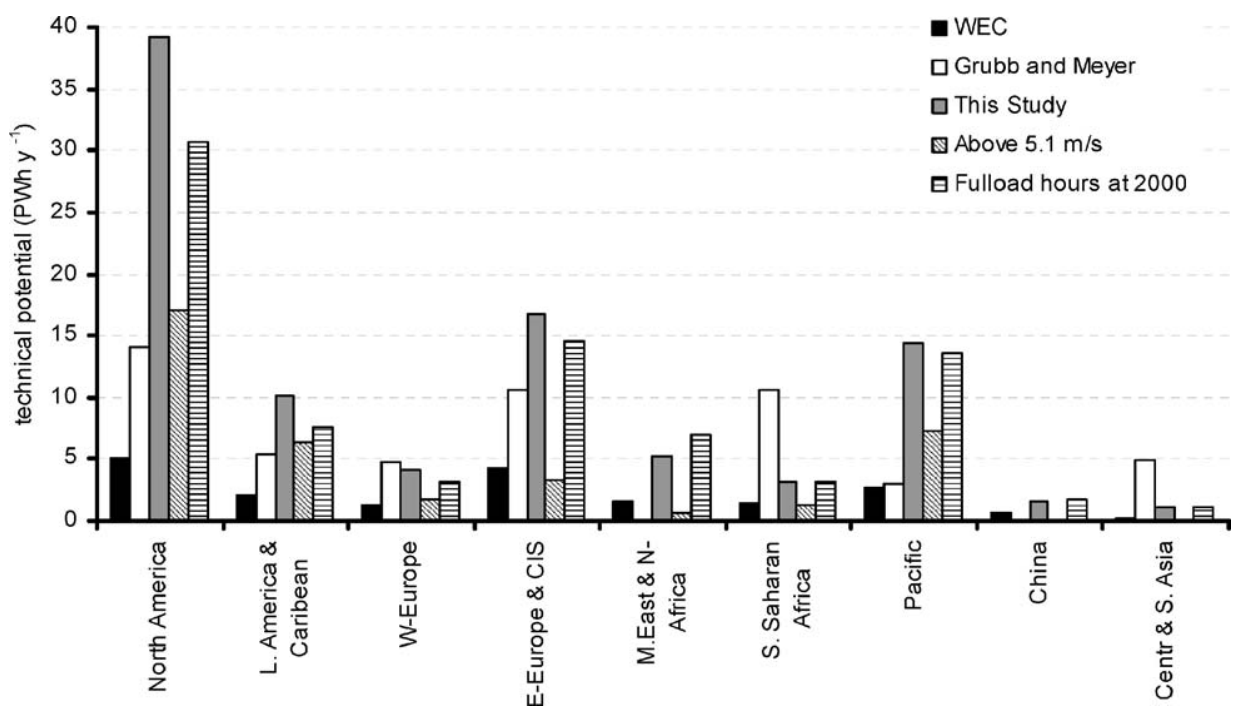

Fig. 13. The technical potential assessed in this study compared to three other technical potential assessments and the results if three different assumptions are used.

comparison, we adjusted some input parameters and main assumptions. We assessed the technical potential using assumptions similar to those used in the other studies.

First, all studies included only sites where 'wind resources can be exploited'. Grubb and Meyer define these sites as having wind speeds above $6.0 \mathrm{~m} \mathrm{~s}^{-1}$, the WEC defined the sites as having wind speeds above $5.1 \mathrm{~m} \mathrm{~s}^{-1}$ at $10 \mathrm{~m}$. We used an exclusion wind speed of $4.0 \mathrm{~m} \mathrm{~s}^{-1}$ at $10 \mathrm{~m}$. When the restriction of 5.1 instead of $4.0 \mathrm{~m} \mathrm{~s}^{-1}$ at $10 \mathrm{~m}$ is used, our estimate of the global potential falls by $60 \%$, with large decreases (to even nil) in South Asia (see Fig. 13). The reason given for excluding these sites was the decision to include 'exploitable' sites only. We have included all sites where technically speaking large-scale wind turbines could be installed. Nonexploitable sites end up in the upper part of the costsupply curve. The IEA/OECD study includes only sites where wind electricity can be generated at costs below $0.20 \mathrm{US} \mathrm{kWh}^{-1}$. If we apply this restriction to our data, our figures reduce only marginally (see Figs. 12 and 13).

Second, the WEC excluded areas at a distance of more than $50 \mathrm{~km}$ from the existing grid. Due to lack of data on the electricity grid used in the WEC study, the effect of this assumption could not be studied quantitatively. Including this constraint may reduce our results.

Third, the overall power density is an important factor. The WEC study assumed a global average power density of $0.33 \mathrm{MW} \mathrm{km}^{-2}$. This number is based on empirical studies concerning the optimal power density at national level and includes site constraints. IEA/OECD limits the power density to $0.15 \mathrm{MW} \mathrm{km}^{-2}$ based on empirical values in Denmark. We use a maximum power density of $4 \mathrm{MW} \mathrm{km}^{-2}$ in the suitable area. The calculated power density in the total area varies between $0.01 \mathrm{MW} \mathrm{km}^{-2}$ in Western Africa and $1.1 \mathrm{MW} \mathrm{km}{ }^{-2}$ in Canada. As a global average, we calculate a slightly higher figure, $0.37 \mathrm{MW} \mathrm{km}^{-2}$. This makes our results only slightly higher than WEC but higher 
than IEA/OECD by a factor of about 2. Grubb and Meyer do not use a fixed or upper limit for the power density (see Fig. 13).

Fourth, in this study, the electricity output is calculated in a similar way as the WEC study and the study by Grubb and Meyer did, i.e., on the basis of the full-load hours. However, in the two previous studies, the amount of full-load hours per turbine was fixed in at 2000 and $2277 \mathrm{~h}$, respectively. If a fixed amount of full-load hours at $2000 \mathrm{~h}$ is assumed, our results decrease $14 \%$ to a global technical potential of $83 \mathrm{PWh}_{\text {year }}{ }^{-1}$.

Finally, differences are caused by differences in the input parameter $V_{10}$. We could not reassess our calculations with the wind speed data of the previous studies. Hence, we were unable to compare the influence of the input parameter $V_{10}$ on the results. Fellows (2000) have been able to compare his data with other digital data for the USA. It was concluded that their database underestimated the wind speed and corrections were made for the overall results. This could not be done in this study.

From the comparison with previous studies, it can be seen that our study yields in a higher technical potential. However, as we include the regional cost-supply curves, part of the technical potential neglected by previous studies end up in the upper part of our cost-supply curves. Important parameters that further explain the differences are the assumed power density at grid cell level and the method used to assess the technical output of a wind turbine.

\subsection{Discussion of main assumptions}

We discuss three aspects of the assessment of the geographical and technical potential and the cost of wind electricity: the method used, the input data used in the assessment, and the implication of this method and these input parameters for the results and conclusions.

\subsubsection{Approach}

First of all, it should be realised that when the technical potential is restricted to the onshore sites, only part of the total wind energy technical potential is included. The technical offshore potential mentioned for Europe is $8.5 \mathrm{PWh}_{\text {year }}{ }^{-1}$ at sites where the water is up to $50 \mathrm{~m}$ deep and at a global level, values are mentioned of $37 \mathrm{PWh}^{\mathrm{year}}{ }^{-1}$ (Leutz et al., 2001). Hence, the overall wind electricity potential (onshore + offshore) is significantly larger (about a factor of 1.4) compared to the onshore figures only.

Furthermore, it is stressed that the potential and cost as assessed in this study do not include grid integration, transmission and distribution of the electricity and the storage capacity that might be required due to the intermittent character of wind. As mentioned earlier, the wind regime can be represented by a Weibull distribution function over the year or month. However, even over a shorter time period, the wind resource fluctuates. This complicates the integration of wind electricity in the grid and accounts for additional costs.

\subsubsection{Input data}

The discussion of the input data is structured in Table 5. It shows the accuracy and sensitivity of the data. The sensitivity is discussed in Section 7.1. Input is considered to be strongly accurate if its value is measured or otherwise empirically supported by (several) 
Table 5

The accuracy and sensitivity of the input parameters

\begin{tabular}{lll}
\hline & Accuracy & Sensitivity \\
\hline $\begin{array}{l}\text { Geographical potential } \\
w_{i}\end{array}$ & Weak & Strong \\
Technical potential & & \\
$V_{10}$ & Fair & Strong \\
$\eta_{\mathrm{ar}}$ & Strong & Low \\
$\eta_{\mathrm{a}}$ & Strong & Low \\
$P_{\mathrm{r}}$ & Strong & Low \\
$D$ & Weak & Strong \\
& & \\
Cost of wind electricity & & Low \\
O\&M & Strong & Low \\
\hline
\end{tabular}

literature sources. The parameters that are derived from measurable values are considered fair. Parameters that are not validated in the literature or are closely connected to personal values are considered to be weakly accurate. The sensitivity is derived from the ratio between the range of the input parameter and the range of the results as well as on the range of the calculated lowest wind energy production cost.

Parameters that are highly sensitive and fairly or weakly accurate are: $D, V_{10}$ and $w_{i}$. In particular, the values of $D$ and $w_{i}$ are open to discussion. Furthermore, the database containing the average wind speeds is subject to discussion. The values are probably conservative, resulting, for instance, in a vanishing geographical and technical potential in South and South East Asia. Moreover, the observation data coverage for Oceania is limited. On the basis of this analysis, in combination with a comparison of the data with the data in the European and USA, Indian and South East Asian wind atlases, we believe that our estimate of the technical potential is on the lower side due to the underestimation of the annual mean wind speed in at least India and South East Asia. Results should therefore be treated with care particularly for South and South East Asia and Oceania.

\section{Conclusions}

The aim of our study was to assess the theoretical, geographical, technical and economic potential of onshore wind energy by constructing regional cost-supply curves for wind energy. The onshore global technical potential is estimated to be $96 \mathrm{PWh} \mathrm{year}^{-1}$, or about 6 times the present (2001) world electricity consumption. Assuming an average wind turbine output of 2000 full-load hours, this potential is about 2000 times the annually produced wind energy at present (2001). To supply this technical potential, an area of 1.1 Gha is required assuming a power density of $4 \mathrm{MW} \mathrm{km}{ }^{2}$. This is similar to the total global grassland area or the size of about China. The regionally highest technical potential is found in the USA (21 $\mathrm{PWh}_{\text {year }}{ }^{-1}$ ). Lowest figures are found in African regions, Eastern Europe and South East Asia. 
In most regions, the technical potential exceeds the electricity consumption. The highest surplus is found in East Africa where the technical potential exceeds the present consumption level more than 300 times. In OECD Europe, the technical potential of wind electricity is about 2 times the present electricity consumption. In Eastern Europe, the technical potential does not exceed the present consumption level.

Globally, roughly an amount equal to the present (2001) global electricity consumption is available at costs less than $0.07 \mathrm{US} \$ \mathrm{kWh}^{-1}$, spread over most regions. At a cost of $0.06 \mathrm{US} \$ \mathrm{kWh}^{-1}$ or below, about $7 \mathrm{PWh}$ year ${ }^{-1}$ wind electricity may be generated, half of the present electricity consumption. This potential can be found mainly in Canada, USA, South America, former USSR and OECD Europe (see Table 3 ). The actual estimate of the technical potential of onshore wind energy (for given cutoff costs) depends critically on assumptions about acceptable power density and landuse constraints.

Since the database for the mean annual wind speed is rather conservative compared to wind speeds in the literature, we can expect our results to represent an underestimate of the technical potential. Therefore, the results for South and South East Asia and Oceania should be considered with care.

\section{Acknowledgements}

We are grateful to Jan Coelingh (Ecofys), Paul Smulders and Erik Lysen (UCE) for commenting on draft versions and their suggestions during the process.

\section{Appendix A}

Overall equation:

$$
E=\sum_{i=1}^{n} f_{i} A_{i} a_{i} \eta_{\mathrm{a}} \eta_{\mathrm{ar}}\left(N_{\mathrm{t}, i} P_{\mathrm{r}}\right) \alpha_{1} V_{10, i}\left\{\frac{\ln \left(\left[C P_{\mathrm{r}}^{w}\right] / z_{0, i}\right)}{\ln \left(10 / z_{0, i}\right)}\right\} \alpha_{2}
$$

\section{List of variables used}

$P \quad$ Power per $\mathrm{m}^{2}$ swept area $\left(\mathrm{W} \mathrm{m}^{-2}\right)$

$\rho \quad$ Air density $\left(\mathrm{kg} \mathrm{m}^{-3}\right)$

$v \quad$ Wind speed $\left(\mathrm{m} \mathrm{s}^{-1}\right)$

$\mathrm{Gp}_{i} \quad$ Geographical potential in cell $i\left(\mathrm{~km}^{2}\right)$

$\mathrm{Tp}_{i} \quad$ Theoretical potential in cell $i(\mathrm{kWh})$

$o_{i} \quad$ Fraction of onshore area in cell $i(-)$

$f_{i} \quad$ Suitability factor for sociogeographical constraints in cell $i$ (-)

$A_{i} \quad$ Total area in cell $i\left(\mathrm{~km}^{2}\right)$

$u_{i} \quad$ Urban area in cell $i(-)$

$a_{i} \quad$ Binary weighting factor for altitude (-)

$b_{i} \quad$ The suitability factor for bioreserves $(-)$ 
$w_{i} \quad$ Suitability factor for land-use and land-cover function of cell $i(-)$

$r_{i} \quad$ Suitability factor for wind regime restrictions $(-)$

$H \quad$ Height (m)

$v_{H} \quad$ Wind speed at height $H\left(\mathrm{~m} \mathrm{~s}^{-1}\right)$

$z_{0} \quad$ Roughness length of the surface (m)

$V \quad$ Annual average wind speed $\left(\mathrm{m} \mathrm{s}^{-1}\right)$

$C$ Constant used for the determination of hub height

$w \quad$ Constant used for the determination of hub height

$P_{\mathrm{r}} \quad$ Rated power of wind turbine $(\mathrm{kW})$

Cf Capacity factor (-)

$v_{\mathrm{i}} \quad$ Cut-in wind speed $\left(\mathrm{m} \mathrm{s}^{-1}\right)$

$k \quad$ Weibull shape factor

$a \quad$ Weibull scaling factor

$v_{\mathrm{r}} \quad$ Rated wind speed $\left(\mathrm{m} \mathrm{s}^{-1}\right)$

$v_{\mathrm{O}} \quad$ Cut-out wind speed $\left(\mathrm{m} \mathrm{s}^{-1}\right)$

$h_{\mathrm{f}} \quad$ Full-load hours per year $\left(\mathrm{h}_{\text {year }}{ }^{-1}\right)$

$\alpha_{1} \quad$ Constant for the determination of full-load hours (h year ${ }^{-1} \mathrm{~m}^{-1} \mathrm{~s}^{-1}$ )

$\alpha_{2} \quad$ Constant for the determination of full-load hours (h year ${ }^{-1}$ )

$D_{i} \quad$ Installed power density in grid cell $i$ in the suitable area $\left(\mathrm{kW} \mathrm{km}^{-2}\right)$

$N_{\mathrm{t}, i} \quad$ Number of turbines per $\mathrm{km}^{2}$ in grid cell $i(-)$

$\eta_{\mathrm{a}} \quad$ Average availability of the turbines (-)

$\eta_{\mathrm{ar}} \quad$ Wind farm array efficiency (-)

$E_{i} \quad$ Annual energy output of a grid cell $\left(\mathrm{kWh}\right.$ year $\left.{ }^{-1}\right)$

$I_{\mathrm{t}} \quad$ Specific investment costs (US\$ $\mathrm{kW}^{-1}$ )

$I_{\mathrm{t} 0} \quad$ Specific investment costs for a reference turbine (US\$ $\mathrm{kW}^{-1}$ )

$P_{\mathrm{r} 0} \quad$ Capacity of the reference turbine $(\mathrm{kW})$

$\beta \quad$ Scaling factor (-)

I Total investment costs (US\$ $\mathrm{kW}^{-1}$ )

$\zeta \quad$ Turbine costs as a fraction of the total investment costs (-)

$\mathrm{Coe}_{i} \quad$ Production cost of electricity in grid cell $i\left(\mathrm{US} \$ \mathrm{kWh}^{-1}\right.$ )

$\gamma \quad$ Annuity factor (-)

$\varepsilon \quad$ Cost of operation and maintenance, as a fraction of $I(-)$

$r \quad$ Interest rate $(-)$

$L \quad$ Economic lifetime (year)

\section{References}

ABB, 1998. Renewable Energy-Status and Prospects. ABB, Baden-Dattwil.

Abed, K.A., El-Mallah, A.A., 1997. Capacity factor of wind turbines. Energy 22 (5), 487-491.

Ackermann, T., Soeder, L., 2002. An overview of wind energy-status 2002. Renewable and Sustainable Energy Reviews 6, 67-128.

AWEA, 2000. Wind Energy Outlook. American Wind Association, Washington, DC, p. 4.

Belward, A., Loveland, T., 1995. The IGBP-DIS 1 km land cover project. In: Curran, P.J., Robertson, Y.C. (Eds.), Remote Sensing in Action. University of Southampton, Southampton, pp. 1099-1106.

Beurksens, H.J.M., 1999. Trends in the development and implementation of wind energy technology. AWEA Conference, Burlington, USA. 
BP, 2001. BP statistical review of world energy. Available at www.BP.com.

British Wind Energy Association, 2000. Planning for Wind Energy-A Guide for Regional Targets. BWEA, London, p. 23.

BTM, 2001. International wind energy development-world market update 2000. BTM Consult Aps, p. 65.

Bundesverband WindEnergie, 2001. Windenergie. Osnabrück.

Cabooter, Y., DeWilde, L., et al., 1997. An inventory of locations suitable for wind energy in Flanders region, V.U.B.O.D.E., p. 7.

Cabooter, Y., Dewilde, L., Langie, M., 1999. An inventory of locations suitable for wind energy in Flanders regions. European Wind Energy Conference, Nice, France.

Chapman, J., Wise, S., 1998. Expanding Wind Power: Can Americans Afford It? p. 25. Washington, DC.

Danish Wind Turbine Manufactures Association. Available at: www.windpower.dk.

de Noord, M., 1999. Large Scale Offshore Wind Energy-Costs Analysis and Integration in the Dutch Electricity Market ECN, Petten.

de Vries, B.J.M., van Vuuren, D.P., Jansen, M.A., den Elzen, M., 2002. The Targets IMage Energy Model Regional (TIMER), Technical Documentation. RIVM, Bilthoven.

Dodge, D.M., 2001. Illustrated history of wind power development. TelosNet.

EIA, 1999. Assumptions to the Annual Energy Outlook 1999-Renewable Fuels Module, p. 9.

Elliot, D.L., Schwartz, M.N., 1993. Wind Energy Potential in the United States Pacific Northwest Laboratory.

Elliot, D.L., Holladay, C.G., Barchet, W.R., Foote, H.P., Sandusky, W.F., 1986. Wind Energy Resource Atlas of the United States. Pacific Northwest Laboratory, Golden, Colorado, p. 210.

European Commission, 1999. Wind Energy-The Facts. European Commission, Luxembourg.

EWEA, 2001. European review: the top 12 markets, wind directions. Available at www.ewea.org.

EWEA and Greenpeace, 2002. Windforce 12, A Blueprint to Achieve 12\% of the World's Electricity from Wind Power by 2020, EWEA and Greenpeace, 50 .

Fellows, A., 2000. The Potential of Wind Energy to Reduce Carbon dioxide Emissions. Garrad Hassan, Glasgow, p. 146 .

Goldemberg, J., 2000. World Energy Assessment, New York, United Nations Development Programme, United Nations Department of Economic and Social Affairs. World Energy Council, p. 508.

Grubb, M.J., Meyer, N.I., 1993. Wind energy: resources, systems, and regional strategies. In: Johansson, T.B., Kelly, H., Reddy, A.K.N., Williams, R.H. (Eds.), Renewable Energy: Sources for Fuels and Electricity. Island Press, Washington, DC, pp. 157-212.

Hoogwijk, M., de Vries, B., Winkel, J., Turkenburg, W., 2003. Assessment of the potential of photovoltaic energy. Energy Economics (submitted for publication).

Hoogwijk, M., Faaij, A., Eickhout, B., de Vries, B., Turkenburg, W., 2004. Potential of biomass under four landuse scenarios. Biomass and Bioenergy (submitted for publication).

IEA, 2002. World Energy Outlook 2002. 523 Paris.

IMAGEteam, 2001. The IMAGE 2.2 Implementation of the SRES Scenarios: A Comprehensive Analysis of Emissions, Climate Change and Impacts in the 21st Century. National Institute for Public Health and the Environment, Bilthoven.

IPCC, 2000. Special Report on Emission Scenarios. Cambridge Univ. Press, Cambridge.

Johansson, T.B., Kelly, H., Reddy, A.K.N., Williams, R.H., 1993. Renewable fuels and electricity for a growing world economy — defining and achieving the potential. In: Johansson, T.B., Kelly, H., Reddy, A.K.N., Williams, R.H. (Eds.), Renewable Energy: Sources for Fuels and Electricity. Island Press, Washington, DC, pp. 1-71.

King Hubbert, M., 1971. The energy resources of the earth. Scientific American 225, 60-84.

Laali, A.-R., Louche, A., Meyer, L.-J., 1996. Influence of wind farm capacity, turbine size and wind speed on production cost: analysis of the actual market trend. European Union Wind Energy Conference, Göteborg.

Lazarus, M., 1993. Towards a Fossil Free Energy Future. Stockholm Environment Institute, Boston, p. 240.

Lemming, J., Morthorst, P.E., Hansen, L.H., Andresen, P.D., Jensen, P.H., 1999. O\&M Costs and Economical Lifetime of Wind Turbines. European Wind Energy Conference, Nice.

Leutz, R., Ackermann, T., Suzuki, A., Akisawa, A., Kashiwagi, T., 2001. Technical Offshore Wind Energy Potentials Around the Globe. European Wind Energy Conference and Exhibition, Copenhagen, Denmark.

Loveland, T.R., Belward, A.S., 1997. The IGBP-DIS global $1 \mathrm{~km}$ cover data set Discover. First results. International Journal of Remote Sensing 18, 3289-3295. 
Lysen, E.H., 1982. Introduction to Wind Energy, Amersfoort, SWD, Steering Committee Wind Energy Developing Countries, p. 310.

Matthies, H.G., Nath, C., Schellin, T.E., Garrad, A.D., Wastling, M.A., Quarton, D.C., Wei, J., Scherweit, M., Siebers, T., 1995. Study of Offshore Wind Energy in the EC. Verlag Natuerliche Energie, Brekendorf.

Morthorst, P.E., 1998. Wind Power Development—Status and Perspectives. Risø National Laboratory, Roskilde, p. 27.

National Wind Coordinating Committee, 1997. Wind energy resources. Wind Energy Series, 4.

Neij, L., 1999. Cost dynamics of wind power. Energy 24, 375-389.

New, M., Hulme, M., Jones, P., 1997. A 1961-1990 Mean Monthly Climatology of Global Land Areas. Climate Research Unit, Norwich.

New, M., Hulme, M., Jones, P., 1999. Representing Twentieth Century Space-Time Climate Variability: Part I. Development of a 1961-1991 Mean Monthly Terrestrial Climatology. American Meteorological Society, pp. 820-856. March.

Petersen, E.L., Troen, I., Frandsen, S., Hedefaard, K., 1981. Wind Atlas for Denmark. Risoe, Roskilde, p. Z229.

Pimentel, D., Rodrigues, G., Wane, T., Abrams, R., Goldberg, K., Staecker, H., Ma, E., Brueckner, L., Trovato, L., Chow, C., Govindarajulu, U., Boerke, S., 1994. Renewable energy: economic and environmental issues. Bioscience 44 (8), S36-S47.

Rangarajan, S., 1998. Wind Energy Resource Survey in India, Bangalore, Indian Institute of Tropical Meteorology, Field Research Unit.

Rehfeldt, K., Schwenk, B., Molly, J.P., 1997. Sensitivity study of different parameters concerning the energy generating costs of wind turbines. European Wind energy Conference, Dublin.

Shell, 1995. The evolution of the world's energy system 1860-2060: extracts of a study by Shell International London.

Solutions, T., 2001. Wind Energy Resource Atlas of South East Asia. New York.

Stevens, M.J.M., Smulders, P.T., 1979. The estimation of the parameters of the Weibull wind speed distribution for wind energy utilization purposes. Wind Engineering 3 (2), 132-145.

Turkenburg, W.C., 2000. Renewable energy technologies. In: Goldemberg, J. (Ed.), World Energy Assessment. UNDP, Washington, DC, pp. 220-272.

van Wijk, A.J.M., Coelingh, J.P., 1993. Wind Power Potential in the OECD Countries, Department of Science, Technology and Society, Utrecht University, Utrecht, p. 35.

Wieringa, J., Rijkoort, P.J., 1983. Windklimaat van Nederland Staatsuitgeverij, Den Haag.

Windstats, 2000. Windstats Newsletter 13 (1), p. 10.

World Energy Council, 1994. New Renewable Energy Resources_A Guide to the Future, vol. 387. Kogan Page, London. 